\title{
Creation of the WATCH Forcing Data and Its Use to Assess Global and Regional Reference Crop Evaporation over Land during the Twentieth Century
}

\section{Article}

Published Version

Weedon, G. P., Gomes, S., Viterbo, P., Shuttleworth, W. J., Blyth, E., Österle, H., Adam, J. C., Bellouin, N., Boucher, O. and Best, M. (2011) Creation of the WATCH Forcing Data and Its Use to Assess Global and Regional Reference Crop Evaporation over Land during the Twentieth Century. Journal of Hydrometeorology, 12 (5). pp. 823-848. ISSN 1525-7541 doi: https://doi.org/10.1175/2011JHM1369.1 Available at https://centaur.reading.ac.uk/34633/

It is advisable to refer to the publisher's version if you intend to cite from the work. See Guidance on citing.

Published version at: http://dx.doi.org/10.1175/2011JHM1369.1

To link to this article DOI: http://dx.doi.org/10.1175/2011JHM1369.1

Publisher: American Meteorological Society

All outputs in CentAUR are protected by Intellectual Property Rights law, including copyright law. Copyright and IPR is retained by the creators or other copyright holders. Terms and conditions for use of this material are defined in the End User Agreement. 


\section{www.reading.ac.uk/centaur}

\section{CentAUR}

Central Archive at the University of Reading

Reading's research outputs online 


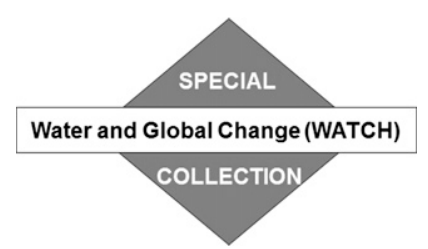

\title{
Creation of the WATCH Forcing Data and Its Use to Assess Global and Regional Reference Crop Evaporation over Land during the Twentieth Century
}

\author{
G. P. Weedon, ${ }^{*}$ S. Gomes, ${ }^{+}$P. Viterbo, ${ }^{+}$W. J. Shuttleworth,${ }^{\#}$ E. Blyth,${ }^{@}$ H. Österle,${ }^{\&}$ \\ J. C. ADAM, ${ }^{* *}$ N. Bellouin, ${ }^{++}$O. BOUCher, ${ }^{++}$AND M. BEST ${ }^{++}$ \\ * Met Office Hadley Centre, Joint Centre for Hydrometeorological Research, Wallingford, United Kingdom \\ ${ }^{+}$Instituto Dom Luiz, University of Lisbon, Lisbon, Portugal \\ \# Department of Hydrology and Water Resources, The University of Arizona, Tucson, Arizona \\ ${ }^{\circledR}$ Centre for Ecology and Hydrology, Joint Centre for Hydrometeorological Research, Wallingford, United Kingdom \\ \& PIK Potsdam, Potsdam, Germany \\ ** Washington State University, Pullman, Washington \\ ${ }^{++}$Met Office Hadley Centre, Exeter, United Kingdom
}

(Manuscript received 3 September 2010, in final form 24 February 2011)

\begin{abstract}
The Water and Global Change (WATCH) project evaluation of the terrestrial water cycle involves using land surface models and general hydrological models to assess hydrologically important variables including evaporation, soil moisture, and runoff. Such models require meteorological forcing data, and this paper describes the creation of the WATCH Forcing Data for 1958-2001 based on the 40-yr ECMWF Re-Analysis (ERA-40) and for 1901-57 based on reordered reanalysis data. It also discusses and analyses modelindependent estimates of reference crop evaporation. Global average annual cumulative reference crop evaporation was selected as a widely adopted measure of potential evapotranspiration. It exhibits no significant trend from 1979 to 2001 although there are significant long-term increases in global average vapor pressure deficit and concurrent significant decreases in global average net radiation and wind speed. The near-constant global average of annual reference crop evaporation in the late twentieth century masks significant decreases in some regions (e.g., the Murray-Darling basin) with significant increases in others.
\end{abstract}

\section{Introduction}

As the earth's whole climate system slowly changes there are likely to be greater and faster regional changes. Studies of the impacts of these changes on essential services such as fresh water supply are being made by many researchers (e.g., Harding et al. 2011) with the change in evaporation being a key aspect. Observations of large-scale evaporation over the last half century (the most studied period) are, however, not available. Consequently, models of evaporation are frequently used as an alternative. In such models the key factors that determine changes in evaporation are changes in meteorological factors such as radiation, wind speed, air temperature, and humidity.

Corresponding author address: G. P. Weedon, Met Office Hadley Centre, Joint Centre for Hydrometerological Research, Maclean Building, Wallingford OX10 8BB, United Kingdom.

E-mail: graham.weedon@metoffice.gov.uk
Studies have analyzed pan evaporation data (Roderick and Farquhar 2002; Roderick et al. 2007) and reported changes in the external drivers on evaporation when there is no change in available water. In Australia these studies have demonstrated that large-scale change in wind speed (global stilling) is responsible for an observed drop in pan evaporation, although decreases-increases in radiation (global dimming-brightening) are perhaps responsible for changes elsewhere. Shuttleworth et al. (2009) demonstrated that it is not always possible to use pan evaporation to diagnose large-scale change in external drivers of actual evaporation. This is because some changes in the drivers of pan evaporation are caused by feedbacks in the atmospheric planetary boundary layer caused by altered actual evaporation in the area surrounding the pan. However, they also demonstrated that it is not possible to assume that changes in pan evaporation are equal and opposite to changes in surrounding actual evaporation, as suggested by Bouchet (1963), since changes in the variables controlling evaporation are a mixture of regional 


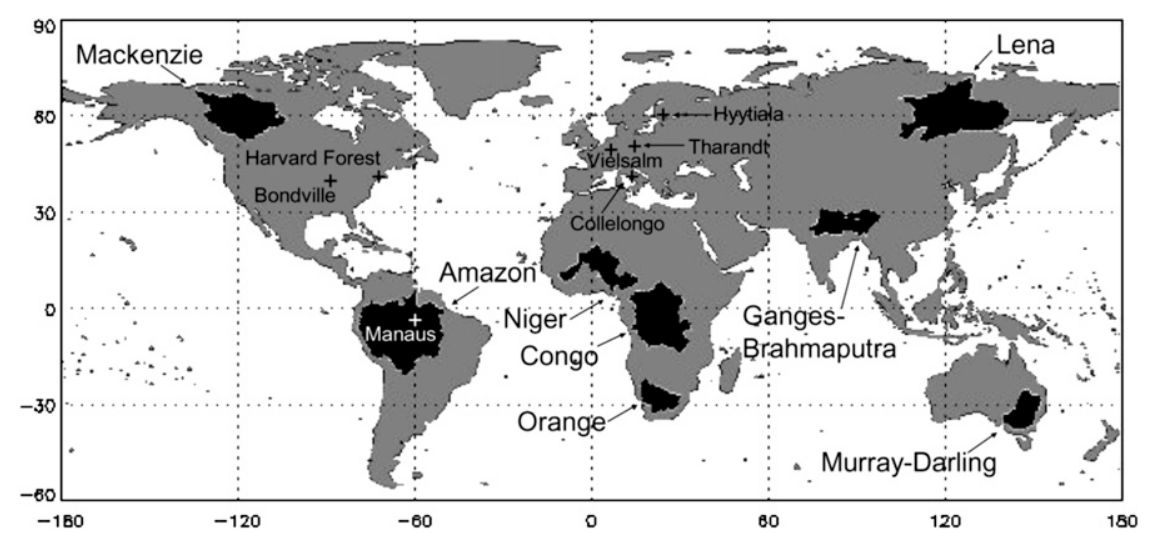

FIG. 1. Location map for the FLUXNET sites used in Figs. 2-4 (indicated by plus signs) and for the large river basins considered in Figs. 7-9 (indicated in black).

atmospheric feedbacks superposed on modified largescale atmospheric circulation.

In their comprehensive review, Hobbins et al. (2008) point out that researchers interested in global evaporation need an accurate assessment of the external drivers of the evaporation process. However, because of nonlinearity in the relationships between the drivers of evaporation (particularly temperature) it is not possible to make such an assessment using daily average meteorological data. Instead, accurate assessment requires data that resolve the full diurnal cycle. This paper describes the creation of the Water and Global Change (WATCH) Forcing Data (WFD), a dataset that is available for the whole of the twentieth century and that resolves the full diurnal cycle. An analysis of changes in the external drivers of evaporation that is relevant to both researchers and water-resource engineers is also made.

The European Union WATCH project (www.eu-watch. org) seeks to assess the terrestrial water cycle in the context of global change in the twentieth and twenty-first centuries. A major component of the study is use of land surface models (LSMs) and general hydrological models (GHMs) to calculate changes in hydrologically important variables such as evaporation, soil moisture, and runoff (Haddeland et al. 2011). For both types of model, meteorological "forcing" (or "driving") data (air temperature, rainfall/snowfall, etc.) are required at subdaily time steps for the LSMs and daily time steps for the GHMs. The 40-yr European Centre for Medium-Range Weather Forecasts (ECMWF) Re-Analysis (ERA-40) product, which provided the basis data used in the derivation of the WFD, was derived from successive short-term integrations of a general circulation model (GCM) that assimilated [via three-dimensional variational data assimilation (3D-Var)] various satellite data along with atmospheric soundings and land and sea surface observations (Uppala et al. 2005). The reanalysis procedure used to create ERA-40 merged global subdaily observations with a prior estimate based on short integrations of a comprehensive GCM, allowing for uncertainties in each, using a GCM configuration that was consistent, as opposed to the progressively refined and improved GCMs that are used in routine weather forecasting. As explained below, the WFD were derived from the surface variables of the ERA-40 reanalysis product for the period 1958 to 2001, but from reordered ERA-40 data for the period 1901 to 1957.

The several models involved in the WATCH project calculate hydrological variables using the WFD in different ways, but a key aspect of the models is the way in which evaporation is estimated (Haddeland et al. 2011). LSMs typically estimate actual evaporation by evaluating the energy balance at the subdaily time scale, whereas GHMs typically require estimates of daily-average "potential" evapotranspiration and then assess actual evaporation by adjusting this estimate to allow for the water availability. In this paper an assessment is made of changes in global twentieth-century potential evaporation independent of any specific LSM or GHM as estimated via the WFD themselves. Consideration is also given to regional variations in the selected large river basins shown in Fig. 1.

\section{The WATCH Forcing Data}

The WFD consist of subdaily, regularly (latitudelongitude) gridded, half-degree resolution, meteorological forcing data. The variables included are (i) wind speed at $10 \mathrm{~m}$, (ii) air temperature at $2 \mathrm{~m}$, (iii) surface pressure, (iv) specific humidity at $2 \mathrm{~m}$, (v) downward longwave radiation flux, (vi) downward shortwave radiation flux, (vii) rainfall rate, and (viii) snowfall rate. These global data are stored at 67420 points over land (excluding 
TABLE 1. Creation of the meteorological variables in the WFD.

\begin{tabular}{|c|c|c|}
\hline $\begin{array}{l}\text { Meteorological } \\
\text { variable }\end{array}$ & $\begin{array}{l}\text { Elevation correction after bilinear } \\
\text { interpolation }\end{array}$ & Data used for monthly bias correction \\
\hline 10-m wind speed & Nil & Nil \\
\hline 2-m temperature & Via environmental lapse rate & $\begin{array}{l}\text { CRU average temperature (corrected) and } \\
\text { average diurnal temperature range. }\end{array}$ \\
\hline 10-m surface pressure & Via changes in 2-m temperature & Nil \\
\hline 2-m specific humidity & $\begin{array}{l}\text { Via changes in } 2-\mathrm{m} \text { temperature } \\
\text { and surface pressure }\end{array}$ & Nil \\
\hline Downward longwave radiation & $\begin{array}{l}\text { Via fixed relative humidity, changes } \\
\text { in } 2-\mathrm{m} \text { temperature, surface } \\
\text { pressure, and specific humidity }\end{array}$ & Nil \\
\hline Downward shortwave radiation & Nil & $\begin{array}{l}\text { CRU average cloud cover and effects of } \\
\text { changing atmospheric aerosol loading. }\end{array}$ \\
\hline Rainfall rate & Nil & $\begin{array}{l}\text { CRU number of "wet days", GPCCv4 } \\
\text { precipitation totals, ERA-40 rainfall/total } \\
\text { proportion, and rainfall gauge catch corrections. }\end{array}$ \\
\hline Snowfall rate & Nil & $\begin{array}{l}\text { CRU number of "wet" days, GPCCv4 } \\
\text { precipitation totals, ERA-40 snowfall/total } \\
\text { proportion, and snowfall gauge corrections. }\end{array}$ \\
\hline
\end{tabular}

the Antarctic), with the land-sea mask used being that defined by the Climatic Research Unit (CRU; New et al. 1999, 2000) in netCDF format using the Assistance for Land-Surface Modelling Activities (ALMA) convention (see http://www.lmd.jussieu.fr/ polcher/ALMA/). Variables vi-viii are not readily interpolated and are stored at three-hourly time steps as in the basic ERA-40 data, but to save space variables $\mathrm{i}-\mathrm{v}$ are stored at 6-hourly time steps with code provided to give variabledependent interpolation to the three-hourly time step.

\section{a. WATCH Forcing Data 1958-2001}

\section{1) INTRODUCTION}

Generation of the WFD for the late twentieth century described in detail by Weedon et al. (2010) adopted the procedures described by Ngo-Duc et al. (2005) and Sheffield et al. (2006), but with the changes summarized in Table 1. Processing involved bilinear interpolation of each variable from the $1^{\circ} \mathrm{ERA}-40$ grid to the $0.5^{\circ} \mathrm{CRU}$ land-sea mask. To maintain consistency, elevation corrections were then made sequentially to the interpolated temperature, surface pressure, specific humidity, and downward longwave radiation (in that order, because elevation correction of later variables requires use of previously corrected variables).

In several respects the ERA-40 data product is superior to the earlier National Center for Atmospheric Research-National Centers for Environmental Prediction (NCAR-NCEP) reanalysis used in deriving other forcing datasets (e.g., Uppala et al. 2005), but the 2-m temperatures in ERA-40 are known to lack some climatic trends and to exhibit an overall bias (Betts and
Beljaars 2003; Simmons et al. 2004; Hagemann et al. 2005) despite the assimilation of relevant surface observations. Comparison of diurnal extremes in nearsurface temperature in the NCAR-NCEP, ERA-40, and the (more recent) Japanese Meteorological Agency (JMA) 25-yr reanalysis (JRA-25) data reveals problems in all 3 data products (Pitman and Perkins 2009), particularly with respect to minimum temperature. For this reason the monthly average interpolated and elevationcorrected temperatures from ERA-40 were also biascorrected (Weedon et al. 2010). Because the CRU3 data (Brohan et al. 2006) were not available at $0.5^{\circ}$ resolution for all the required observations during creation of the WFD, CRU TS2.1 gridded observations were used for this bias correction (New et al. 1999, 2000; Mitchell and Jones 2005).

The use of CRU observations for monthly bias correction inevitably incorporates inaccuracies related to creation of the gridded products. Nevertheless, the CRU interpolation methodology based on 1961-90 anomalies (New et al. 1999, 2000) includes allowance for the "correlation length" of the variables involved, and elevation corrections and inhomogeneities between stations have been adjusted while the variable station coverage through time and spatially is documented by New et al. (1999, 2000) and Mitchell and Jones (2005). Despite these limitations the CRU dataset has been widely used for investigating global terrestrial changes through the twentieth century (e.g., Déry and Wood 2005; Gedney et al. 2006; Dang et al. 2007; Piao et al. 2009).

The CRU temperature data used include some (albeit rare) inhomogeneities. Specifically, there were steplike 
offsets in the values that can span several years at particular sites and also some single month outliers (which were identified as being more than five standard deviations away from the 1958-2001 monthly mean). Prior to their use for bias correction, the inhomogeneities were removed from CRU data using the method of Österle et al. (2003) and single month outlier values were replaced with the local calendar-month mean (Weedon et al. 2010). Average monthly diurnal temperature ranges were also corrected using the CRU data (Weedon et al. 2010).

\section{2) CORRECTIONS TO VARIABLES OTHER THAN PRECIPITATION}

The relative humidity implied by the original ERA-40 temperature, pressure, and specific humidity was interpolated bilinearly to the half-degree grid following Cosgrove et al. (2003), and the resulting values then used with the elevation- and bias-corrected temperature and pressure to calculate specific humidity. Using this method maintains consistency between variables and also avoids supersaturation. CRU observations of vapor pressure were used to make monthly average checks of the values so derived, but they were not used for bias correction because this would have compromised consistency.

Using the ERA-40 data means that there is no global unidirectional bias in the WFD downward longwave radiation with respect to the average National Aeronautics and Space Administration (NASA) Surface Radiation Budget (SRB) product (Weedon et al. 2010). This contrasts with the work of Ngo-Duc et al. (2005) and Sheffield et al. (2006), where global unidirectional bias related to the NCAR-NCEP reanalysis necessitated correction via the SRB product. Comparison with selected FLUXNET data (Weedon et al. 2010) also showed that it was not necessary to make a monthly bias correction of the WFD downward longwave radiation using the SRB3 quality-controlled longwave (QCLW) product (see http://eosweb.larc.nasa.gov/PRODOCS/srb/ table_srb.html) interpolated to half degree.

Downward shortwave radiation was adjusted at the monthly time scale using CRU cloud cover and the local linear correlation between monthly average (interpolated) ERA-40 cloud cover and downward shortwave radiation (Sheffield et al. 2006; Weedon et al. 2010). Troy and Wood (2009) compared unadjusted ERA-40 radiation fluxes with other reanalysis products and observations across northern Eurasia. ERA-40 does not include adjustments for the effects of seasonal and decadal variations in atmospheric aerosol loading on downward shortwave radiation fluxes (Uppala et al. 2005), although long-term changes in aerosol loading can significantly influence downward shortwave radiation fluxes (e.g., Wild et al. 2008). A correction was therefore made for the effects of tropospheric and stratospheric aerosols on downward surface fluxes of shortwave radiation using twentieth-century aerosol optical depths (AODs) taken from a GCM combined with lookup tables of radiative transfer calculations.

Distributions of tropospheric AOD at $0.55 \mu \mathrm{m}$ for the twentieth century were taken from simulations with the atmospheric component of the Hadley Centre Global Environmental Model version 2 (HadGEM2-A; Martin et al. 2006; Collins et al. 2008). HadGEM2-A includes representation of the following tropospheric aerosol species: sulfate, mineral dust, sea salt, black carbon from fossil fuel and from biomass burning, and secondary organic aerosols (Bellouin et al. 2007). Stratospheric aerosols from volcanic eruptions were available as zonal means (Sato et al. 1993, dataset updated in 2002). Aerosol radiative effects are represented in both the clear-sky (cloud-free) portion of each GCM grid box and the portion that is cloudy. Thus, the calculations made on the GCM grid and interpolated to half degree provided correction to clear-sky downward radiation that accounted for the direct and indirect effect of aerosols in the troposphere and the direct effect in the stratosphere, and also for the effect of aerosols on cloudy-sky downward radiation in the troposphere (Weedon et al. 2010). These corrections assume that stratospheric aerosols do not interact with tropospheric clouds to influence cloudysky radiation fluxes, and there is also no allowance for indirect effects of aerosols on ice clouds (cirrus) in the stratosphere. The aerosol load-corrected shortwave radiation was compared to the SRB version 3 qualitycontrolled shortwave (QCSW) product and both datasets were validated against FLUXNET observations; the comparison showed (Weedon et al. 2010) that it was not necessary to bias-correct the WFD downward shortwave radiation using the SRB3 QCSW product.

\section{3) CORRECTIONS FOR RAINFALL AND SNOWFALL}

The generation of the precipitation data for the WFD involved six steps (Weedon et al. 2010): 1) bilinear interpolation, 2) combining rainfall and snowfall totals while retaining the rainfall/snowfall ratio for each location and time step, 3) adjusting the number of "wet" (i.e., rain or snow) days per month to match the CRU TS2.1 observations, 4) adjusting the monthly precipitation totals to match version four of the Global Precipitation Climatology Centre full product (GPCCv4), 5) reassigning the precipitation into rain and snow using the original ratio, and 6) adjusting the monthly totals using gridded average precipitation gauge corrections (separately for rainfall and snowfall).

The GPCCv4 full data product used in step 4 is based on gridded precipitation gauge measurements comparable to 
the CRU totals (i.e., they exclude satellite information and do not include gauge corrections; T. Fuchs 2008, personal communication). This observational dataset was chosen for adjusting monthly precipitation totals rather than CRU TS2.1 totals because their station coverage is much better, particularly at high latitudes and for the end of the twentieth century (Rudolf and Schneider 2005; Schneider et al. 2008; Fuchs et al. 2009; see http:// gpcc.dwd.de/). Exploratory precipitation processing using the CRU totals for correction instead of GPCCv4 had revealed minor differences during the boreal winter (December-February) and major differences in northeast India-Bangladesh and northern Amazonia during boreal summer (June-August; Weedon et al. 2010).

The method adopted for wet-day correction is the main difference in the derivation of previous precipitation forcing datasets. Ngo-Duc et al. (2005), for example, did not correct wet days, whereas Sheffield et al. (2006) used a statistical correction (Sheffield et al. 2004) that was designed to cope with spurious standing wavelike patterns in the high northern-latitude wet-day characteristics of the NCAR-NCEP data. However, the Sheffield et al. correction meant that spatial continuity of individual precipitation events was sometimes compromised (see Fig. 7 of Sheffield et al. 2004), and it also required the adjustment of several associated variables when wet days were "created" to match the CRU data.

The main weakness with ERA-40 precipitation is the presence of too many wet days in the tropics (Betts and Beljaars 2003; Hagemann et al. 2005; Uppala et al. 2005) rather than spurious standing wave patterns. The approach used to redress this weakness was to compare the number of wet days in a particular month at each halfdegree grid square with the CRU data. When and where there were too many wet days in the interpolated data (specifically two days or more than the CRU count), the number of days with precipitation in the month was reduced by progressively setting the rainfall-snowfall rate to zero on the day with the lowest daily total precipitation until the number of wet days matched the CRU count. Resetting of the precipitation rate was made without reference to the associated specific humidity.

This method for wet-day correction has the advantage that, because only the smallest daily totals are reset, the spatial continuity and coherence of significant (nondrizzle) frontal precipitation across grid boxes is not compromised. This is important in the context of the WATCH project because it means that large-scale (multigrid box) hydrological modeling remains meaningful at the daily scale. For locations where there were too few wet days per month relative to the CRU observations, no changes were made, thus avoiding the need to artificially modify downward shortwave, specific humidity, and 2-m temperature on dry days to make them consistent with conversion to wet days (cf. Sheffield et al. 2006).

The correction method just described was successful in that the number of tropical wet days was adjusted to match the CRU data and the adjustment of precipitation totals based on GPCCv4 totals is not problematic. However, for the (very few) locations and times when there were too few wet days in the interpolated ERA-40 data, the adjustment of monthly precipitation totals sometimes implied extraordinarily high precipitation rates, and it was expedient to limit these "outlier" rates to a rate corresponding to the $99.999 \%$ lognormal probability precipitation rate for the relevant calendar month and grid box (Weedon et al. 2010). As a result, some precipitation totals are less than the GPCCv4 totals in the WFD in a few locations and months. In a small number of grid boxes and some months precipitation rates are close to zero in the 1958-2001 ERA-40 data. The monthly bias correction then had the effect of increasing these rates such as to imply there was spurious background drizzle between more normal precipitation events. In semiarid areas this is inconsistent with local climatic conditions but, fortunately from the point of view of hydrological modeling, this spurious low-level background precipitation is not significant.

Once the number of wet days and precipitation totals had been adjusted, the rainfall and snowfall proportion at each time step and grid box were assigned to the ratio of rain and snow originally diagnosed by the ERA-40 reanalysis (i.e., step 5). This means that the full atmospheric profile is involved is allocating precipitation to rain and snow rather than (say) simply using a threshold of $0^{\circ} \mathrm{C}$ in $2-\mathrm{m}$ temperature. The subsequent precipitation gauge catch correction used separate average calendar monthly catch ratios for rainfall and snowfall rates at each half-degree grid box taken from Adam and Lettenmaier (2003), who originally provided either rainfall or snowfall catch ratios for each calendar month and grid box. No attempt was made to adjust precipitation rates to allow for the effects of orography (cf. Adam et al. 2006).

\section{4) VALIDATION}

Part of the validation process for the WFD involved use of FLUXNET data (www.fluxnet.ornl.gov/fluxnet/), which were obtained (with permission) and then gapfilled for selected years at seven sites (see Fig. 1) (Persson et al. 2000; Aubinet et al. 2001; Araújo et al. 2002; Suni et al. 2003; Meyers and Hollinger 2004; Grünwald and Bernhofer 2007; Urbanski et al. 2007; Göckede et al. 2008). This selection of sites allowed direct comparison of data from the mid-1990s to 2001 (consequently restricting the geographic availability of data principally to Europe and North America) and included a variety of latitudes 
and climatic regimes and a variety of land-cover types and elevations.

Weedon et al. (2010) illustrate time series of several variables and also provide spatial comparisons of (a) the seasonal averages of the vapor pressure implied in WFD with data from CRU, (b) WFD downward longwave and shortwave fluxes with bias-corrected versions using SRB satellite averages, and (c) WFD precipitation with a biascorrected version that used CRU monthly totals rather than the GPCCv4 monthly totals. The validation studies discussed here are restricted to consideration of snow-rain transitions, statistical comparison of time series, and illustration of the time series of temperature and precipitation.

The subsidiary figures in Fig. 2 compare the proportion of snowfall relative to total precipitation as a function of near-surface temperature for flux tower sites (excluding snow-free Manaus) with the corresponding proportion at equivalent half-degree grid squares in the WFD. These figures illustrate data only when precipitation rate (snowfall plus rainfall) exceeds $0.5 \mathrm{~mm} \mathrm{~h}^{-1}$; consequently, a snowfall-precipitation ratio of 0 indicates precipitation that is exclusively rainfall rather than 0 precipitation. When flux tower observers arbitrarily assigned the proportion of snow to be exactly $1 / 3,1 / 2$, or $2 / 3$ of the total precipitation, these ratios were not deemed reliable and were excluded from Fig. 2.

Figure 2 shows that in both the WFD and the (original and 3-h aggregated) flux tower observations, the transition between snow and rain is not well defined by using a $0^{\circ} \mathrm{C}$ threshold in 2-m temperature (shown as vertical gray lines). In the flux tower observations rain alone $\left(\right.$ snow $/$ precipitation $=0.0$, precipitation $\geq 0.5 \mathrm{~mm} \mathrm{~h}^{-1}$ ) often occurs below this threshold, while snow alone (snow/ precipitation $=1.0$ ) also occurs above this threshold. Interestingly, between $-15^{\circ}$ and $-2^{\circ} \mathrm{C}$ the WFD (and ERA-40 reanalysis) rarely has precipitation that is exclusively rainfall or snowfall, and in the original flux tower data a mixture of rain and snow is also fairly common. The proportion of half-hourly flux tower data that imply mixed rain and snow depends on latitude. At Hyytiala $\left(61.85^{\circ} \mathrm{N}\right)$ $16.6 \%$ of the data are mixed phase precipitation whereas at Bondville $\left(40.0^{\circ} \mathrm{N}\right)$ just $1.9 \%$ are mixed phase, although these percentages should be considered minima because the artificially defined sleet-wet snow observations (ratios of exactly $0.5,0.333$, and 0.666 ) were excluded from the figure. Overall the results indicate that using the proportions of rain and snow indicated by the WFD in hydrological modeling is likely to be more reliable than assigning a water phase based on a 2-m threshold temperature (cf. Table 1 in Haddeland et al. 2011).

Table 2 gives the squared correlation coefficient $\left(r^{2}\right.$, which indicates the proportion of variance shared by the two time series), the root-mean-square error
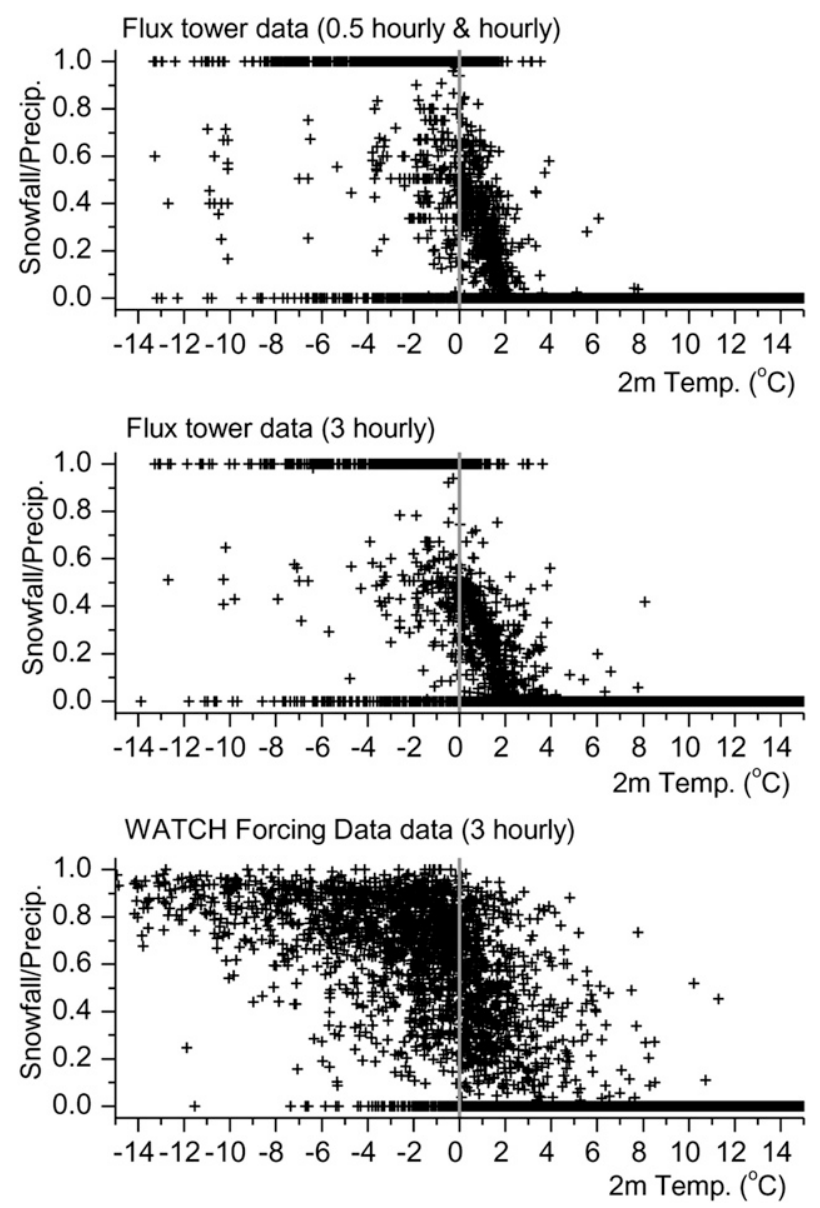

FIG. 2. The proportion of snow (as water equivalent) to total precipitation compared to 2-m temperatures from selected (top),(middle) FLUXNET sites (Fig. 1) and (bottom) in the WFD. Data points are illustrated only when the total precipitation exceeds $0.5 \mathrm{~mm} \mathrm{~h}^{-1}$; hence a snowfall-precipitation ratio of 0 indicates occurrence of rain exclusively. For the FLUXNET data- (top) $1 / 2$ and $1 \mathrm{~h}$ and (middle) $3 \mathrm{~h}$-ratios corresponding to exactly $1 / 3,1 / 2$, and $2 / 3$ snowfall have been excluded (see text). (bottom) The WFD data are illustrated for each $12^{\circ}$ grid box corresponding to the FLUXNET sites (see Table 2 for exact locations). (middle) Indicates the results of aggregating half-hourly (hourly for Harvard Forest) flux tower precipitation data to three-hourly data as compared to the instantaneous three-hourly 2-m temperature (this treatment allows a more appropriate comparison with the WFD).

(RMSE), the mean bias error (MBE, i.e., the mean data point differences), and the lag- 1 autocorrelation ( $\rho_{1}$, the 1 time step serial dependence) between 3-h FLUXNET data and the WFD. The lag-1 autocorrelation characterizes the "red" noise (nonregular) component of time series-smoothly varying data have a value of $\rho_{1}$ near 1.0 whereas very noisy/erratic data have a value near 0.0 . This parameter was determined using the robust spectralfitting method of Mann and Lees (1996) because largeamplitude regular components such as diurnal and annual 
cycles can cause a positive bias. Correlation coefficients were calculated having removed the lag-1 autocorrelation, which otherwise positively biases the calculation, via prewhitening of the time series (i.e., $X_{t, \mathrm{pw}}=X_{t}-\rho_{1} X_{t-1}$, where $X_{t, \mathrm{pw}}$ represents the prewhitened value of the time series at time $t$; e.g., Ebisuzaki 1997). For precipitation and shortwave radiation the number of data points used in the calculation of Student's $t$, used to assess the significance of the correlations, was reduced by excluding from consideration times of zero precipitation and night time values, respectively.

It should be recognized that data in the WFD represent half-degree grid box area averages but FLUXNET data represent very much smaller sensor "footprints" (Göckede et al. 2008). The correlations between these two sources of data are highly significant for all locations and variables, with the notable exception of precipitation at Manaus and Harvard Forest, largely because of the very large sample sizes (Table 2). However, several variables sometimes have large shared variance, specifically 2-m temperature $\left(r^{2}=0.21-0.64\right)$, surface pressure $\left(r^{2}=0.09-0.37\right)$, downward longwave radiation $\left(r^{2}=0.05-0.48\right)$, and downward shortwave radiation $\left(r^{2}=0.65-0.84\right)$. Conversely, correlation of prewhitened specific humidity is low at all sites $\left(r^{2}=0.03-0.12\right)$ although RMSE and mean bias errors are low compared to the means.

In Fig. 3 daily average WFD 2-m temperature is overlaid (in gray) on half-hourly flux tower values (in black). The daily 2-m temperature tracks the center of the half-hourly (hourly for Harvard Forest and Manaus) field data well, indicating that the WFD capture local daily-to-monthly (synoptic) meteorological variability as well as the seasonal cycles. The general similarity in values at the different spatial scales of the WFD and the field observations is symptomatic of the long spatial correlation length of temperature (New et al. 2000).

The only selected flux tower that is located in an area of predominantly convective rainfall is at Manaus in Amazonia. Although the number of wet days each month and monthly total precipitation had been adjusted in the WFD, at the three-hourly time scale the development of cloud and the occurrence of convective rainfall in the reanalysis for this site only poorly match the flux tower observations, even when the latter are aggregated to give three-hourly values. At the other flux tower sites considered, rainfall and snowfall associated with frontal systems in the reanalysis are more likely to match field observations at the daily to monthly time scales because the probability of precipitation is partly influenced by assimilated observations (such as atmospheric pressure). Overall the correlations for precipitation are low $\left(r^{2}=0.000-0.046\right)$ and the root-mean-square error is large. Mean bias error indicates overall mismatch in values over the full duration of the data in Table 2, and the assertion that the match is better at longer time scales is supported by the low absolute values of the MBE compared to the mean precipitation at all locations. Additionally, Fig. 4 shows that at several flux tower sites both the occurrence and intensity of daily precipitation in the WFD show a good match to daily average observations (e.g., Hyytiala and Harvard Forest).

The $r^{2}$ of the prewhitened time series is below, and sometimes far below, 0.1 for wind speed at all sites except Vielsalm, and at Bondville the mean bias error for wind speed is especially large compared to the mean. This is likely to be because the Bondville flux tower is located in an area of crops while the reanalysis treats the full grid square as being forest. As a result, generally high and very variable observed winds are being inappropriately compared with generally low and much less variable modeled forest-cover winds.

At Collelongo correlations are low in comparison with other sites for 2-m temperature, specific humidity, and downward longwave radiation, and the mean bias error is also high for these variables. A likely contribution to these discrepancies is that the flux tower site is $564 \mathrm{~m}$ higher than the grid box average elevation (Table 2). This affects the 2-m temperature (via the environmental lapse rate) and also surface pressure, and these two variables in turn influence specific humidity and downward longwave radiation and hence the mean bias error. It is likely that local topographic factors also led to a mismatch (i.e., low correlations) between the flux tower weather and the grid-square average reanalysis results.

The RMSE for downward shortwave radiation is fairly high $\left(\sim 90 \mathrm{~W} \mathrm{~m}^{-2}\right)$ at all sites and especially so at Manaus $\left(109 \mathrm{~W} \mathrm{~m}^{-2}\right)$. This is expected because convective clouds are difficult to model correctly in GCMs so there is likely to be a large mismatch with the field observations at the 3-h scale. However, absolute mean bias errors are acceptable (2-23 $\mathrm{W} \mathrm{m}^{-2}$; Table 2) and the correlations are high since the CRU fractional cloud cover was used to correct mean downward shortwave radiation in the WFD at the monthly scale [see section 2a(2)].

The lag-1 autocorrelations show an impressive level of agreement at all localities for all variables with the exception of wind speed and precipitation. The reanalysis wind speed often has a higher lag-1 autocorrelation than observations (i.e., the variability between the three hourly time steps is too low), although for some unknown reason the opposite is true at Hyytiala. At all the sites the precipitation lag-1 autocorrelation is always very much higher in the WFD than for observations, indicating that, compared with reality, there is too much serial 
TABLE 2(a)-(g). Correlation and statistics comparing 3-h FLUXNET data with WFD. Quantities are: $r^{2}$ adjusted $=$ Pearson's correlation coefficient for prewhitened data, $P=$ probability that $r^{2}$ adjusted is not statistically distinguishable from 0 , RMSE $=$ rootmean-square error, $\mathrm{MBE}=$ mean bias error, and $\rho 1=$ lag- 1 autocorrelation. Note that the comparison is between field-scale tower measurements and half-degree area averages. The results for temperature and associated variables for Collelongo are influenced by the difference between the flux tower and the grid area average via the lapse rate (the tower is $564 \mathrm{~m}$ higher). At Bondville, the wind speed data are affected by comparison of tower data for crops with the ERA-40 reanalysis treatment of the grid square as forest (the field data are windier).

(a) Hyytiala, Finland (evergreen needleleaf forest) $1997-2001$. Flux tower: $61.85^{\circ} \mathrm{N}, 24.30^{\circ} \mathrm{E}$ at $181 \mathrm{~m}$. WFD grid center: $61.75^{\circ} \mathrm{N}, 24.25^{\circ} \mathrm{E}$ at avg $138 \mathrm{~m} ; 14608$ 3-h data points.

\begin{tabular}{|c|c|c|c|c|c|c|c|c|}
\hline Variable (units) & $\begin{array}{c}\text { Flux } \\
\text { tower } \\
\text { average }\end{array}$ & $\begin{array}{c}\text { WFD } \\
\text { grid average }\end{array}$ & $\begin{array}{c}r^{2} \\
\text { adjusted }\end{array}$ & $P$ & RMSE & MBE & $\begin{array}{c}\text { Flux tower } \\
\rho 1\end{array}$ & $\begin{array}{c}\text { WFD } \\
\rho 1\end{array}$ \\
\hline $\begin{array}{l}\text { 10-m wind speed } \\
\left(\mathrm{m} \mathrm{s}^{-1}\right)\end{array}$ & 2.94 & 2.42 & 0.080 & $<0.001$ & 1.239 & -0.520 & 0.647 & 0.542 \\
\hline 2-m temperature $\left({ }^{\circ} \mathrm{C}\right)$ & 4.20 & 4.24 & 0.552 & $<0.001$ & 2.201 & 0.043 & 0.980 & 0.964 \\
\hline $\begin{array}{l}\text { 10-m surface } \\
\text { pressure }(\mathrm{hPa})\end{array}$ & 991.5 & 993.2 & 0.365 & $<0.001$ & 3.45 & 1.73 & 0.988 & 0.991 \\
\hline $\begin{array}{l}\text { 2-m specific } \\
\text { humidity }\left(\mathrm{kg} \mathrm{kg}^{-1}\right)\end{array}$ & 0.0047 & 0.0047 & 0.120 & $<0.001$ & 0.0007 & 0.0000 & 0.981 & 0.975 \\
\hline $\begin{array}{l}\text { Downward } \\
\text { longwave }\left(\mathrm{W} \mathrm{m}^{-2}\right)\end{array}$ & 294.19 & 287.53 & 0.188 & $<0.001$ & 31.106 & -6.664 & 0.975 & 0.891 \\
\hline $\begin{array}{l}\text { Downward } \\
\text { shortwave }\left(\mathrm{W} \mathrm{m}^{-2}\right)\end{array}$ & 100.09 & 88.70 & 0.752 & $<0.001$ & 61.254 & -11.397 & 0.740 & 0.743 \\
\hline $\begin{array}{l}\text { Rainfall }+ \text { snowfall } \\
\quad\left[\mathrm{mm}(3 \mathrm{~h})^{-1}\right]\end{array}$ & 0.206 & 0.240 & 0.046 & $<0.001$ & 0.943 & 0.034 & 0.358 & 0.768 \\
\hline
\end{tabular}

(b) Tharandt, Germany (evergreen needleleaf forest) $1997-2001$. Flux tower: $50.69^{\circ} \mathrm{N}, 13.57^{\circ} \mathrm{E}$ at $380 \mathrm{~m}$. WFD grid center: $50.75^{\circ} \mathrm{N}$, $13.75^{\circ} \mathrm{E}$ at avg $430 \mathrm{~m} ; 14608$ 3-h data points.

\begin{tabular}{|c|c|c|c|c|c|c|c|c|}
\hline Variable (units) & $\begin{array}{c}\text { Flux } \\
\text { tower } \\
\text { average }\end{array}$ & $\begin{array}{c}\text { WFD } \\
\text { grid average }\end{array}$ & $\begin{array}{c}r^{2} \\
\text { adjusted }\end{array}$ & $P$ & RMSE & MBE & $\begin{array}{c}\text { Flux tower } \\
\rho 1\end{array}$ & $\begin{array}{c}\text { WFD } \\
\rho 1\end{array}$ \\
\hline $\begin{array}{l}\text { 10-m wind speed } \\
\left(\mathrm{m} \mathrm{s}^{-1}\right)\end{array}$ & 3.40 & 2.80 & 0.038 & $<0.001$ & 1.409 & -0.597 & 0.581 & 0.704 \\
\hline 2-m temperature $\left({ }^{\circ} \mathrm{C}\right)$ & 8.73 & 8.91 & 0.310 & $<0.001$ & 2.710 & 0.177 & 0.975 & 0.944 \\
\hline $\begin{array}{l}\text { 10-m surface } \\
\text { pressure }(\mathrm{hPa})\end{array}$ & 972.2 & 965.1 & 0.089 & $<0.001$ & 9.65 & -7.10 & 0.972 & 0.987 \\
\hline $\begin{array}{l}\text { 2-m specific } \\
\text { humidity }\left(\mathrm{kg} \mathrm{kg}^{-1}\right)\end{array}$ & 0.0057 & 0.0060 & 0.056 & $<0.001$ & 0.0010 & 0.0004 & 0.976 & 0.950 \\
\hline $\begin{array}{l}\text { Downward } \\
\text { longwave }\left(\mathrm{W} \mathrm{m}^{-2}\right)\end{array}$ & 315.15 & 314.79 & 0.049 & $<0.001$ & 27.410 & -0.365 & 0.960 & 0.839 \\
\hline $\begin{array}{l}\text { Downward } \\
\text { shortwave }\left(\mathrm{W} \mathrm{m}^{-2}\right)\end{array}$ & 120.50 & 101.00 & 0.655 & $<0.001$ & 88.589 & -19.493 & 0.683 & 0.659 \\
\hline $\begin{array}{l}\text { Rainfall + snowfall } \\
\quad\left[\mathrm{mm}(3 \mathrm{~h})^{-1}\right]\end{array}$ & 0.285 & 0.321 & 0.025 & $<0.001$ & 1.173 & 0.036 & 0.346 & 0.709 \\
\hline
\end{tabular}

(c) Vielsalm, Belgium (Mixed forest) $1997-2001$. Flux tower: $50.31^{\circ} \mathrm{N}, 6.00^{\circ} \mathrm{E}$ at $450 \mathrm{~m}$. WFD grid center: $50.25^{\circ} \mathrm{N}, 6.25^{\circ} \mathrm{E}$ at avg $503 \mathrm{~m}$; 14608 3-h data points.

\begin{tabular}{|c|c|c|c|c|c|c|c|c|}
\hline Variable (units) & $\begin{array}{c}\text { Flux } \\
\text { tower } \\
\text { average }\end{array}$ & $\begin{array}{c}\text { WFD } \\
\text { grid average }\end{array}$ & $\begin{array}{c}r^{2} \\
\text { adjusted }\end{array}$ & $P$ & RMSE & MBE & $\begin{array}{c}\text { Flux tower } \\
\rho 1\end{array}$ & $\begin{array}{c}\text { WFD } \\
\rho 1\end{array}$ \\
\hline $\begin{array}{l}\text { 10-m wind speed } \\
\left(\mathrm{m} \mathrm{s}^{-1}\right)\end{array}$ & 2.49 & 2.84 & 0.161 & $<0.001$ & 1.119 & 0.345 & 0.614 & 0.702 \\
\hline 2-m temperature $\left({ }^{\circ} \mathrm{C}\right)$ & 8.14 & 9.66 & 0.635 & $<0.001$ & 2.690 & 1.525 & 0.954 & 0.918 \\
\hline $\begin{array}{l}\text { 10-m surface } \\
\text { pressure }(\mathrm{hPa})\end{array}$ & 960.9 & 955.9 & 0.159 & $<0.001$ & 5.56 & -4.99 & 0.968 & 0.988 \\
\hline $\begin{array}{l}\text { 2-m specific } \\
\text { humidity }\left(\mathrm{kg} \mathrm{kg}^{-1}\right)\end{array}$ & 0.0062 & 0.0065 & 0.098 & $<0.001$ & 0.0013 & 0.0003 & 0.955 & 0.925 \\
\hline $\begin{array}{l}\text { Downward } \\
\quad \text { longwave }\left(\mathrm{W} \mathrm{m}^{-2}\right)\end{array}$ & 323.17 & 318.94 & 0.479 & $<0.001$ & 24.473 & -4.224 & 0.935 & 0.807 \\
\hline
\end{tabular}


TABLE 2. (Continued)

(c) Vielsalm, Belgium (Mixed forest) $1997-2001$. Flux tower: $50.31^{\circ} \mathrm{N}, 6.00^{\circ} \mathrm{E}$ at $450 \mathrm{~m}$. WFD grid center: $50.25^{\circ} \mathrm{N}, 6.25^{\circ} \mathrm{E}$ at avg $503 \mathrm{~m}$; 14608 3-h data points.

\begin{tabular}{|c|c|c|c|c|c|c|c|c|}
\hline Variable (units) & $\begin{array}{c}\text { Flux } \\
\text { tower } \\
\text { average }\end{array}$ & $\begin{array}{c}\text { WFD } \\
\text { grid average }\end{array}$ & $\begin{array}{c}r^{2} \\
\text { adjusted }\end{array}$ & $P$ & RMSE & MBE & $\begin{array}{c}\text { Flux tower } \\
\rho 1\end{array}$ & $\begin{array}{c}\text { WFD } \\
\rho 1\end{array}$ \\
\hline $\begin{array}{l}\text { Downward } \\
\text { shortwave }\left(\mathrm{W} \mathrm{m}^{-2}\right)\end{array}$ & 110.89 & 102.35 & 0.731 & $<0.001$ & 74.876 & -8.543 & 0.688 & 0.670 \\
\hline $\begin{array}{l}\text { Rainfall }+ \text { snowfall } \\
{\left[\mathrm{mm}(3 \mathrm{~h})^{-1}\right]}\end{array}$ & 0.314 & 0.394 & 0.039 & $<0.001$ & 1.097 & 0.081 & 0.461 & 0.733 \\
\hline
\end{tabular}

(d) Collelongo, Italy (deciduous broadleaf forest) $1996-2001$. Flux tower: $41.85^{\circ} \mathrm{N}, 13.39^{\circ} \mathrm{E}$ at $1550 \mathrm{~m}$. WFD grid center: $41.75^{\circ} \mathrm{N}, 13.75^{\circ} \mathrm{E}$ at avg $986 \mathrm{~m} ; 17536$ 3-h data points.

\begin{tabular}{|c|c|c|c|c|c|c|c|c|}
\hline Variable (units) & $\begin{array}{c}\text { Flux } \\
\text { tower } \\
\text { average }\end{array}$ & $\begin{array}{c}\text { WFD } \\
\text { grid average }\end{array}$ & $\begin{array}{c}r^{2} \\
\text { adjusted }\end{array}$ & $P$ & RMSE & $\mathrm{MBE}$ & $\begin{array}{c}\text { Flux tower } \\
\rho 1\end{array}$ & $\begin{array}{c}\text { WFD } \\
\rho 1\end{array}$ \\
\hline 10-m wind speed $\left(\mathrm{m} \mathrm{s}^{-1}\right)$ & 1.52 & 2.11 & 0.015 & $<0.001$ & 1.541 & 0.588 & 0.486 & 0.506 \\
\hline 2-m temperature $\left({ }^{\circ} \mathrm{C}\right)$ & 7.34 & 14.91 & 0.206 & $<0.001$ & 8.464 & 7.566 & 0.943 & 0.898 \\
\hline $\begin{array}{l}\text { 10-m surface } \\
\text { pressure }(\mathrm{hPa})\end{array}$ & 840.3 & 896.8 & 0.285 & $<0.001$ & 57.18 & 56.49 & 0.957 & 0.965 \\
\hline $\begin{array}{l}\text { 2-m specific } \\
\text { humidity }\left(\mathrm{kg} \mathrm{kg}^{-1}\right)\end{array}$ & 0.0060 & 0.0088 & 0.033 & $<0.001$ & 0.0036 & 0.0028 & 0.937 & 0.913 \\
\hline $\begin{array}{l}\text { Downward } \\
\text { longwave }\left(\mathrm{W} \mathrm{m}^{-2}\right)\end{array}$ & 303.95 & 292.67 & 0.092 & $<0.001$ & 45.284 & -11.280 & 0.922 & 0.695 \\
\hline $\begin{array}{l}\text { Downward } \\
\quad \text { shortwave }\left(\mathrm{W} \mathrm{m}^{-2}\right)\end{array}$ & 145.07 & 147.35 & 0.747 & $<0.001$ & 95.570 & 2.278 & 0.657 & 0.646 \\
\hline Rainfall + snowfall & 0.398 & 0.329 & 0.008 & $<0.001$ & 2.269 & -0.069 & 0.459 & 0.743 \\
\hline
\end{tabular}

$\left[\mathrm{mm}(3 \mathrm{~h})^{-1}\right]$

(e) Harvard Forest, Massachusetts (deciduous broadleaf forest) $1994-2001$. Flux tower: $42.54^{\circ} \mathrm{N}, 72.17^{\circ} \mathrm{W}$ at $490 \mathrm{~m}$. WFD grid: $42.75^{\circ} \mathrm{N}$, $\left[\mathrm{mm}(3 \mathrm{~h})^{-1}\right]$

(f) Bondville, Illinois (corn/soybean rotation) 1997-2001. Flux tower: $40.00^{\circ} \mathrm{N}, 88.29^{\circ} \mathrm{W}$ at $213 \mathrm{~m}$. WFD grid: $39.75^{\circ} \mathrm{N}, 88.25^{\circ} \mathrm{W}$ at avg 204 m; 14608 3-h data points.

\begin{tabular}{|c|c|c|c|c|c|c|c|c|}
\hline Variable (units) & $\begin{array}{c}\text { Flux } \\
\text { tower } \\
\text { average }\end{array}$ & $\begin{array}{c}\text { WFD } \\
\text { grid average }\end{array}$ & $\begin{array}{c}r^{2} \\
\text { adjusted }\end{array}$ & $P$ & RMSE & $\mathrm{MBE}$ & $\begin{array}{c}\text { Flux tower } \\
\quad \rho 1\end{array}$ & $\begin{array}{c}\text { WFD } \\
\rho 1\end{array}$ \\
\hline 10-m wind speed $\left(\mathrm{m} \mathrm{s}^{-1}\right)$ & 4.25 & 2.81 & 0.023 & $<0.001$ & 2.554 & -1.439 & 0.607 & 0.636 \\
\hline 2-m temperature $\left({ }^{\circ} \mathrm{C}\right)$ & 12.54 & 11.36 & 0.248 & $<0.001$ & 2.118 & 1.182 & 0.964 & 0.954 \\
\hline $\begin{array}{l}\text { 10-m surface } \\
\text { pressure }(\mathrm{hPa})\end{array}$ & 990.6 & 993.0 & 0.536 & $<0.001$ & 2.70 & 2.33 & 0.975 & 0.973 \\
\hline $\begin{array}{l}\text { 2-m specific } \\
\text { humidity }\left(\mathrm{kg} \mathrm{kg}^{-1}\right)\end{array}$ & 0.0079 & 0.0075 & 0.205 & $<0.001$ & 0.0013 & -0.0005 & 0.982 & 0.975 \\
\hline $\begin{array}{l}\text { Downward } \\
\text { longwave }\left(\mathrm{W} \mathrm{m}^{-2}\right)\end{array}$ & 319.24 & 315.02 & 0.102 & $<0.001$ & 28.472 & -4.222 & 0.908 & 0.927 \\
\hline
\end{tabular}


TABLE 2. (Continued)

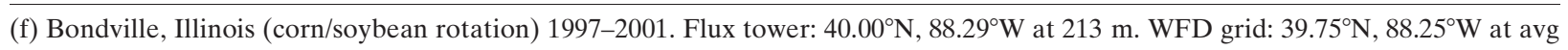
$204 \mathrm{~m} ; 14608$ 3-h data points.

\begin{tabular}{|c|c|c|c|c|c|c|c|c|}
\hline Variable (units) & $\begin{array}{c}\text { Flux } \\
\text { tower } \\
\text { average }\end{array}$ & $\begin{array}{c}\text { WFD } \\
\text { grid average }\end{array}$ & $\begin{array}{c}r^{2} \\
\text { adjusted }\end{array}$ & $P$ & RMSE & $\mathrm{MBE}$ & $\begin{array}{c}\text { Flux tower } \\
\rho 1\end{array}$ & $\begin{array}{c}\text { WFD } \\
\rho 1\end{array}$ \\
\hline $\begin{array}{l}\text { Downward } \\
\text { shortwave }\left(\mathrm{W} \mathrm{m}^{-2}\right)\end{array}$ & 159.00 & 174.28 & 0.837 & $<0.001$ & 88.744 & 15.283 & 0.646 & 0.638 \\
\hline $\begin{array}{l}\text { Rainfall + snowfall } \\
\quad\left[\mathrm{mm}(3 \mathrm{~h})^{-1}\right]\end{array}$ & 0.255 & 0.379 & 0.019 & $<0.001$ & 1.865 & 0.123 & 0.294 & 0.667 \\
\hline
\end{tabular}

(g) Manaus km-34, Brazil (evergreen broadleaf forest) $1999-2001$. Flux tower: $2.61^{\circ} \mathrm{S}, 60.21^{\circ} \mathrm{W}$ at $130 \mathrm{~m}$. WFD grid center: $2.75^{\circ} \mathrm{S}, 60.25^{\circ} \mathrm{W}$ at avg $160 \mathrm{~m} ; 87683$-h data points.

\begin{tabular}{|c|c|c|c|c|c|c|c|c|}
\hline Variable (units) & $\begin{array}{c}\text { Flux } \\
\text { tower } \\
\text { average }\end{array}$ & $\begin{array}{l}\text { WFD } \\
\text { grid average }\end{array}$ & $\begin{array}{c}r^{2} \\
\text { adjusted }\end{array}$ & $P$ & RMSE & MBE & $\begin{array}{c}\text { Flux tower } \\
\rho 1\end{array}$ & $\begin{array}{c}\text { WFD } \\
\rho 1\end{array}$ \\
\hline $\begin{array}{l}\text { 10-m wind speed } \\
\left(\mathrm{m} \mathrm{s}^{-1}\right)\end{array}$ & 2.00 & 1.31 & 0.005 & $<0.001$ & 1.147 & -0.689 & 0.162 & 0.722 \\
\hline 2-m temperature $\left({ }^{\circ} \mathrm{C}\right)$ & 26.03 & 27.03 & 0.313 & $<0.001$ & 2.969 & 1.003 & 0.684 & 0.612 \\
\hline $\begin{array}{l}\text { 10-m surface } \\
\text { pressure }(\mathrm{hPa})\end{array}$ & 1004.2 & 996.1 & 0.347 & $<0.001$ & 9.78 & -8.13 & 0.923 & 0.660 \\
\hline $\begin{array}{l}\text { 2-m specific } \\
\text { humidity }\left(\mathrm{kg} \mathrm{kg}^{-1}\right)\end{array}$ & 0.0178 & 0.0178 & 0.043 & $<0.001$ & 0.0030 & 0.0000 & 0.676 & 0.742 \\
\hline $\begin{array}{l}\text { Downward } \\
\text { longwave }\left(\mathrm{W} \mathrm{m}^{-2}\right)\end{array}$ & 423.97 & 422.49 & 0.269 & $<0.001$ & 17.645 & 4.006 & 0.451 & 0.387 \\
\hline $\begin{array}{l}\text { Downward } \\
\text { shortwave }\left(\mathrm{W} \mathrm{m}^{-2}\right)\end{array}$ & 189.91 & 176.61 & 0.646 & $<0.001$ & 109.304 & 12.938 & 0.564 & 0.584 \\
\hline $\begin{array}{l}\text { Rainfall + snowfall } \\
{\left[\mathrm{mm}(3 \mathrm{~h})^{-1}\right]}\end{array}$ & 0.956 & 0.643 & 0.000 & NS & 3.888 & -0.312 & 0.167 & 0.722 \\
\hline
\end{tabular}

dependence ("memory" or "inertia") in the generation of precipitation in the GCM, at least at these sites.

\section{b. WATCH Forcing Data 1901-57}

To allow modeling of hydrological processes in the WATCH project for the full twentieth century, forcing data are required for $1901-57$, but prior to 1958 reanalysis data from ERA-40 are not available. It is therefore necessary to create a data series of key variables for each grid box that have appropriate characteristics in terms of their diurnal to monthly variations. These data were generated using reordered ERA-40 data a year at a time rather than by using a "weather generator." This approach has the advantage that it ensures spatial coherence of frontal rainfall and snowfall events across grid boxes, which is very important for hydrological modeling of large river basins but which is difficult to ensure in data created using a weather generator. Additionally, the procedures adopted guarantee that the ensuing data has the same temporal variability (diurnal, submonthly variations), the same autocorrelation characteristics (serial dependence from subdiurnal to yearly scales), and the same covariance relationships between variables as during the ERA-40 interval. The procedures used to create the WFD for the period 1901-57 are described below.

\section{1) ERA-40 DATA ASSIGNMENT}

Separate years of ERA-40 data were extracted in their entirety to provide the basic data. The extraction order used (see Table A1) was random, based on the ran1 algorithm of Press et al. (1992), subject to the following constraints:

- Years of ERA-40 data were extracted in random order and assigned in random order without replacement to the years 1901-57 until all 44 of the ERA-40 years from 1958-2001 had been extracted.

- The 13 remaining years of required data needed were assigned again in random order without replacement until all 57 years had been allocated ERA-40 data.

- In the selection process only leap years were assigned to leap years and only nonleap years were assigned to nonleap years.

This selection procedure ensures that as a global average, the statistical characteristics (e.g., overall frequency of daily to seasonal extremes) of the assigned data for 190157 are the same as for 1957-2001. Note that the timing of particular weather events (e.g., exceptional precipitation) is certainly not correct at any particular site, as would also have been the case had a weather generator been used. 


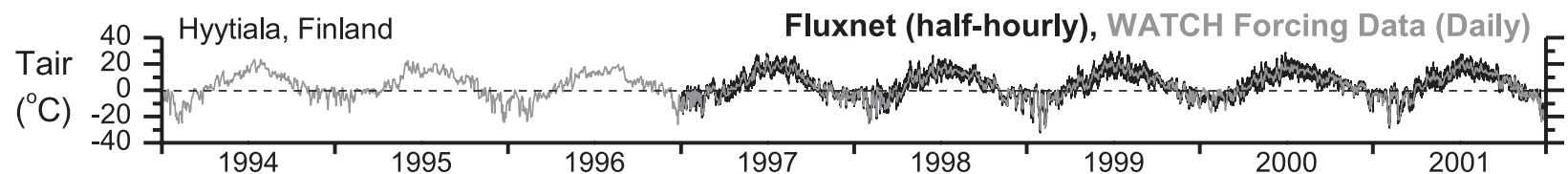

40 Tharandt, Anchor Station, Germany

Tair
$\left({ }^{\circ} \mathrm{C}\right)$

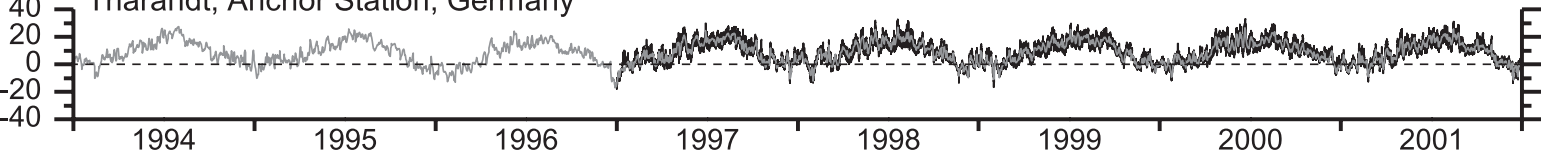

40 Vielsalm, Belgium

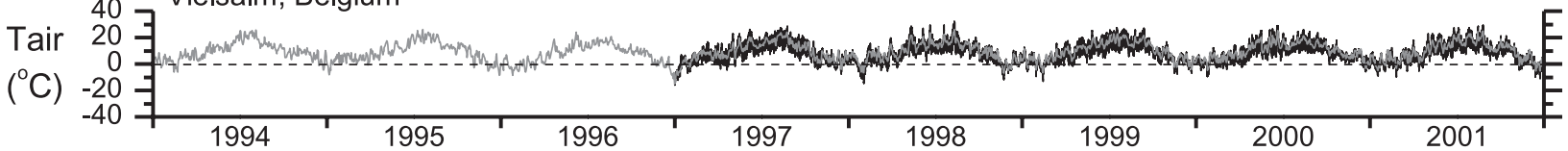
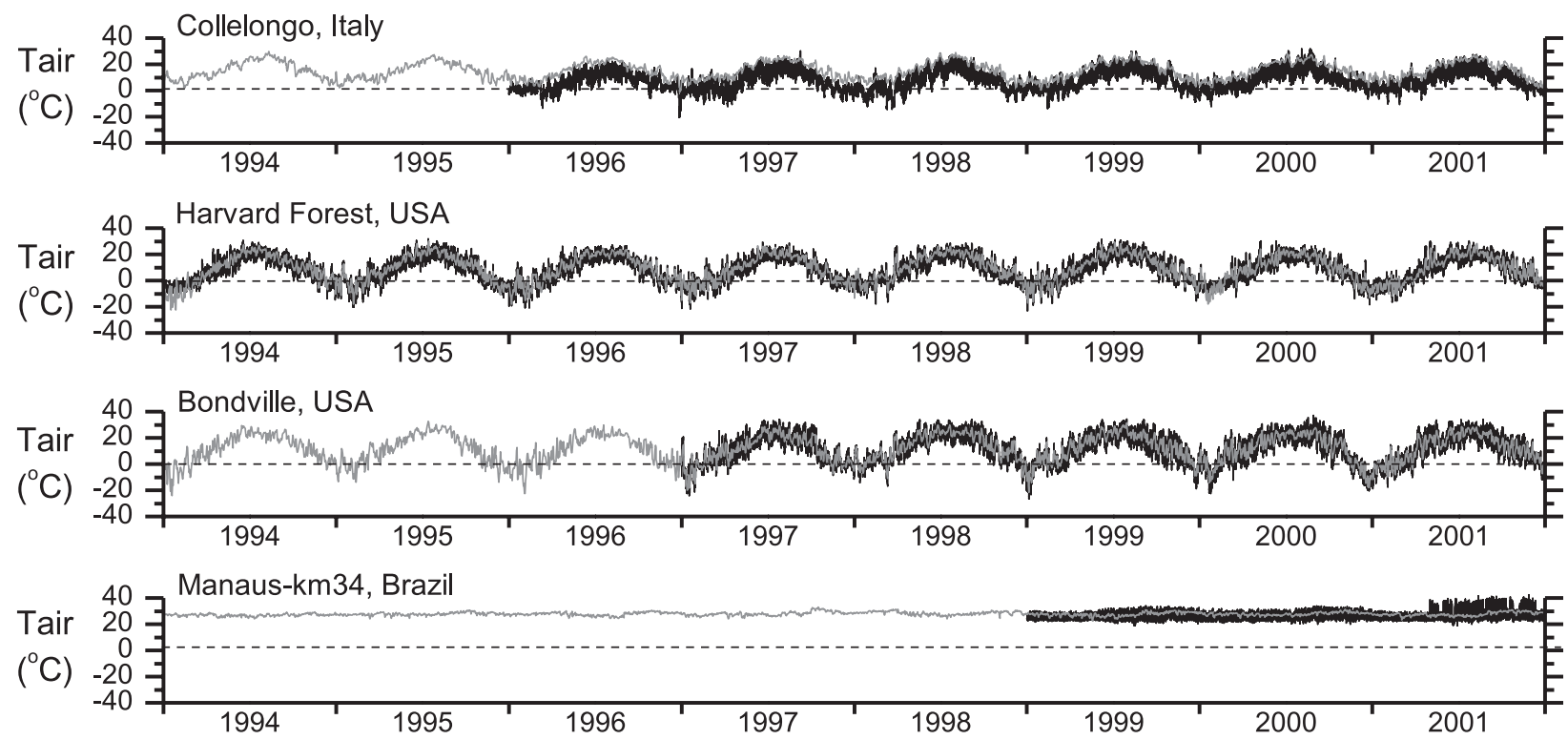

FIG. 3. Comparison of $1 / 2-h$ FLUXNET data (black) with daily average $2-m$ temperatures (Tair) from the WFD at the end of the twentieth century. Note that at Collelongo, the offset between the 2 datasets reflects the effect of the environmental lapse rate (the $1 / 2^{\circ}$ grid square average elevation is about $500 \mathrm{~m}$ lower than the Collelongo FLUXNET site).

\section{2) DATA ADJUSTMENTS}

Exactly the same initial processing steps were applied to the 1901-57 basic data as to the 1958-2001 data (i.e., bilinear interpolation and sequential elevation corrections). The same adjustments of monthly averages (i.e., including the corrections for discontinuities and outliers and diurnal temperature range in the CRU data) were applied to 2-m temperature prior to an elevation correction of surface pressure, specific humidity, and downward longwave radiation. Downward shortwave radiation was again adjusted using the CRU cloud-cover observations, and the effects of seasonal and long-term atmospheric aerosol loading on downward shortwave radiation appropriate for 1901-57 were applied. Total precipitation was also again adjusted using the 1901-57 CRU wet days and the GPCCv4 product monthly precipitation totals prior to making separate rainfall and snowfall gaugecatch corrections.

An important factor to consider in the use of monthly bias correction of the pre-1958 data is the variable temporal and spatial coverage of the CRU and GPCCv4 meteorological station network. This has been documented by New et al. $(1999,2000)$, Mitchell and Jones (2005), and Fuchs et al. (2009; see http://gpcc.dwd.de/). In general the station coverage is worst prior to 1950 especially for precipitation gauges and cloud-cover observations. The regions with the most limited station coverage prior to 1950 are northern central South America, southwest China, the Sahara and central Africa, the Saudi peninsula, and high northern latitudes in Canada and Russia. For specific months and variables, for those 

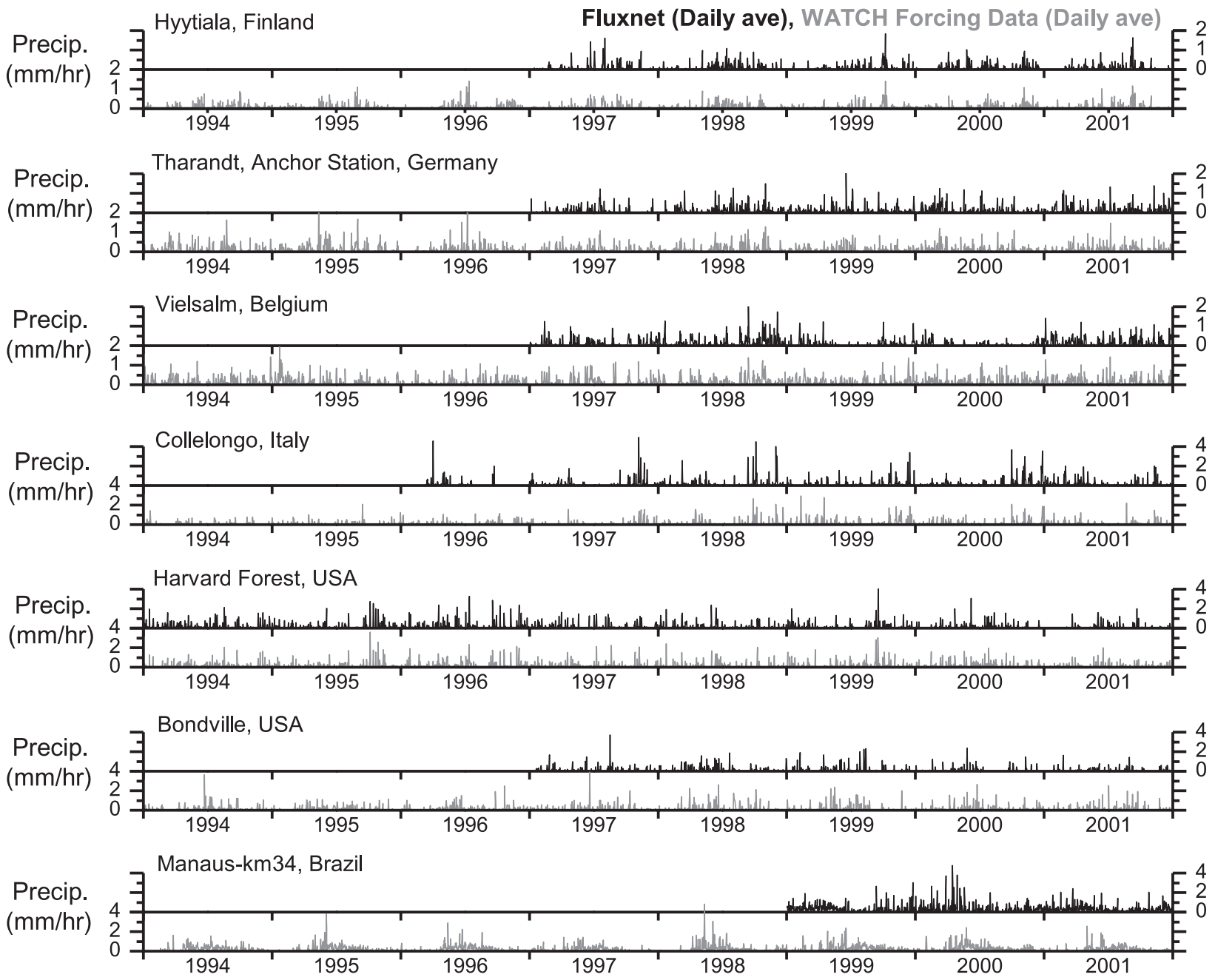

FIG. 4. Comparison of daily precipitation (i.e., rainfall in $\mathrm{mm} \mathrm{day}^{-1}$ plus snowfall as water equivalent $\mathrm{mm}$ day $^{-1}$; in black) at FLUXNET sites with daily precipitation from the WFD (in gray) at the end of the twentieth century.

grid boxes that have too few meteorological observations for reasonable interpolation, CRU substitutes the local monthly 1961-90 climatological average.

\section{3) REMOVAL OF YEAR-END DISCONTINUITIES}

At each grid box, reordering of complete years of ERA-40 data frequently led to year-end discontinuities in wind speed, 2-m temperature, surface pressure, specific humidity, and downward longwave radiation. This was mitigated by applying a "ramp" in the average daily values for these variables between 1 and 5 January for each year from 1902 to 1957 . The mean daily values of variables at each grid box were found for 6 January and for 31 December of the preceding year (values on these days were left unchanged). Based on these, ramp adjustments were applied so that the moving-window, mean 24-h values for 1-5 January changed linearly at each 3-h time step. In this way the mean weather in one year adjusted to the mean weather in the next year over a 5day period, this period being chosen to approximately correspond to the typical transit time of frontal systems, and so that introducing the ramp does not greatly bias the monthly average weather in January. Similar ramps were applied to the last 5 days of December 1957 data to allow a smooth transition between the pre-1958 and the original ERA-40-based 1958-2001 data.

In the case of 2-m temperature, the monthly adjustments to the CRU average temperature and diurnal temperature range were reapplied after creation of yearend ramps so that the ramped temperature agreed with the January CRU monthly averages. No year-end ramps were applied to the rainfall, snowfall, or downward shortwave data because these variables change greatly from day to day largely in response to cloud cover, and imposing a ramp in the daily values for these variables is therefore unrealistic. 

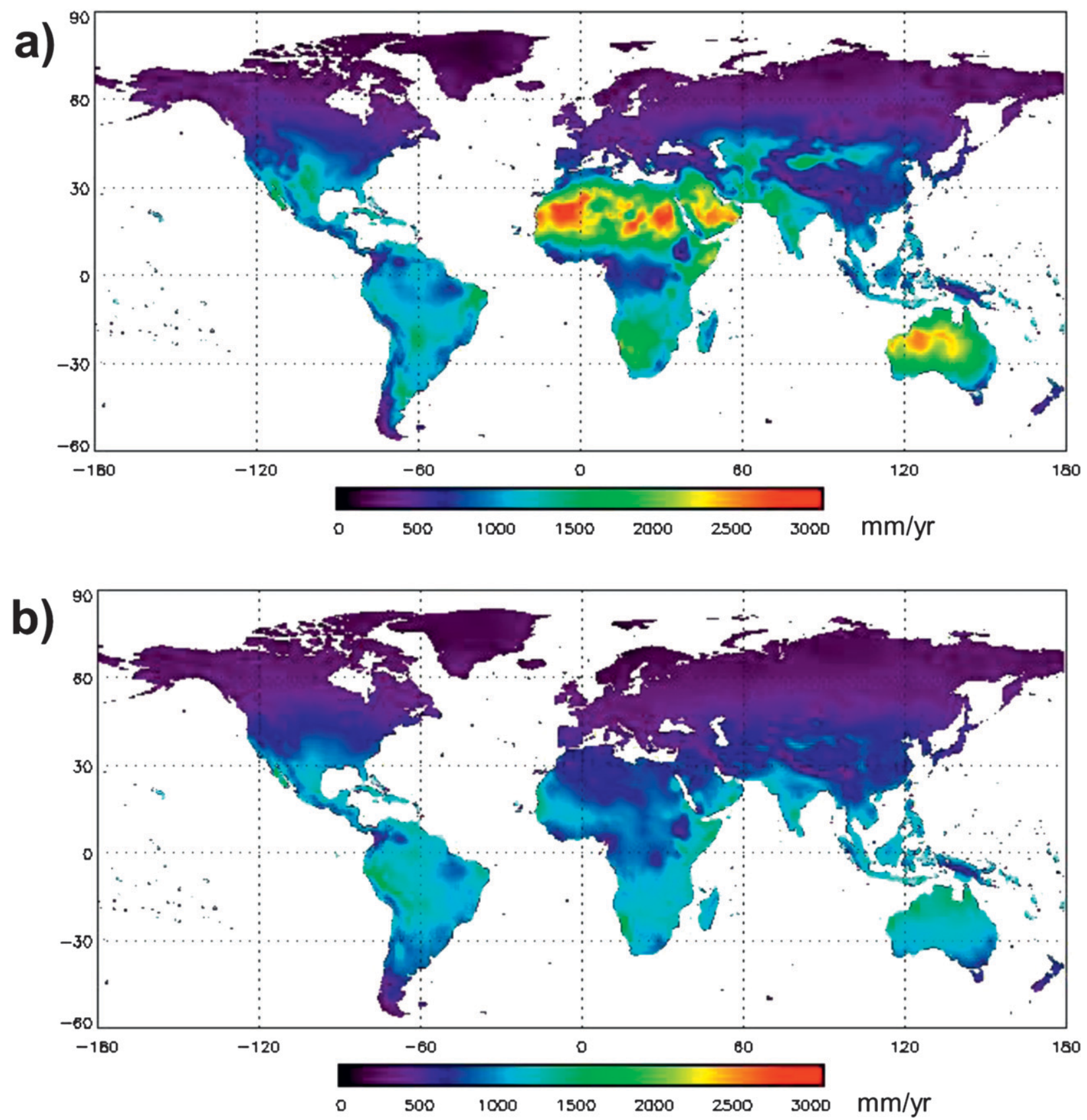

FIG. 5. (a) Map of annual cumulative reference crop evaporation $\left(\mathrm{PET}_{\mathrm{rc}}, \mathrm{mm} \mathrm{yr}^{-1}\right.$ ) for 1979-2001 based on the WFD. (b) Map of the annual cumulative Priestley-Taylor evapotranspiration $\left(\mathrm{PET}_{\mathrm{PT}}\right)$ for 1979-2001 based on the WFD.

\section{Estimation of reference crop evaporation}

To estimate actual evaporation, GHMs typically first calculate an estimate of potential evapotranspiration (PET), which is often based on either the PenmanMonteith equation (Monteith 1965) or the PriestleyTaylor equation (Priestley and Taylor 1972). This calculation seeks to characterize the evaporation (or latent heat) that might be expected from a hypothetical well-watered vegetation-soil surface that is subject to the ambient meteorological forcing variables. Models then estimate the actual evaporation as a proportion of the PET based on the land cover present and the availability of moisture in the soil or on the canopy. Thus PET can always be estimated, even for hot and cold deserts where there is little chance of significant actual evaporation because there is limited moisture available. 

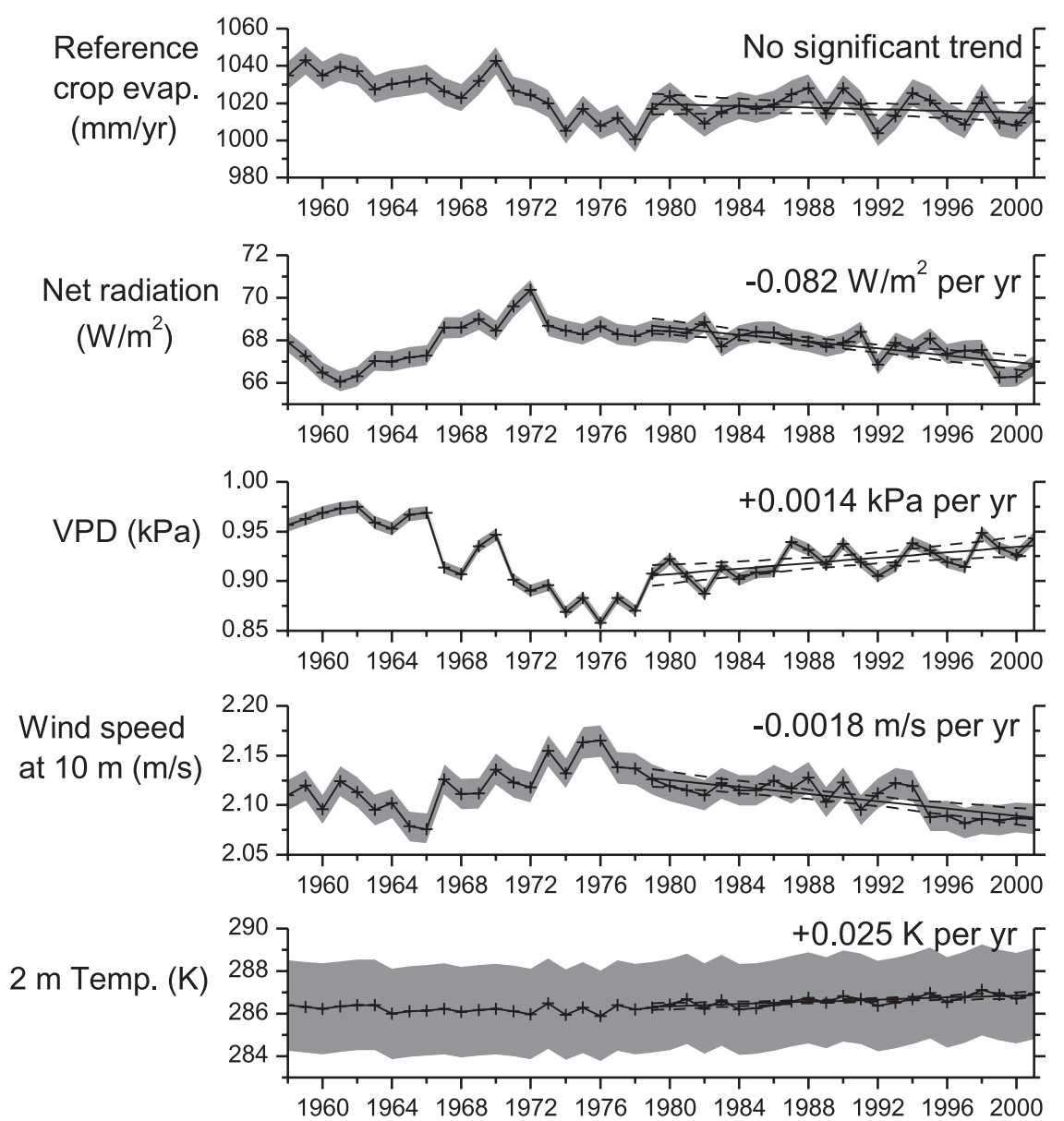

FIG. 6. (top to bottom) Global (excluding Antarctica) land surface annual cumulative reference crop evaporation, net radiation, VPD, 2-m wind speed, and 2-m temperature for 1958-2001 based on the WFD. The averages are area-weighted for grid size according to latitude. The gray shading either side of the averages shown using plus signs indicates the $95 \%$ confidence intervals of the averages. The straight lines indicate the linear regressions for 1979-2001, with associated 95\% confidence limits of the regressions indicated by dashed lines. Figures in the panels indicate the slope (in variable units per year) of the regressions in cases where there is a statistically significant slope (Table 3 includes slope $95 \%$ confidence limits).

Changes in PET implied by the WFD from 1901 to 2001 were evaluated by calculating daily average values, but 3-h time steps of the WFD were used in this calculation because net longwave radiation and saturation vapor pressure vary nonlinearly with temperature. In humid conditions the Priestley and Taylor (1972) equation is sometimes used in GHMs (e.g., Haddeland et al. 2011) to make an estimate of potential evaporation, hereafter called $\mathrm{PET}_{\mathrm{PT}}$ (in units of $\mathrm{W} \mathrm{m}^{-2}$ ); thus,

$$
\operatorname{PET}_{\mathrm{PT}}=\alpha \frac{\Delta A}{(\Delta+\gamma)},
$$

where $\Delta$ is the rate of change of saturated vapor pressure with 2-m temperature, $\gamma$ is the psychometric constant, and $\alpha$ is a factor, usually set to 1.26 (Priestley and Taylor 1972), that apportions the available energy $(A)$ between sensible heat and latent heat from saturated land surfaces. Assuming zero net daily ground heat flux (Allen et al. 1998), at daily time scales the available energy is usually set equal to the net radiation given (Shuttleworth et al. 2009) by

$$
A=(1-a) S+L_{n},
$$

where $a$ is the albedo (often set as 0.23 for vegetated surfaces), $S$ is the downward shortwave radiation flux, and $L_{n}$ is the net longwave (upward minus downward) radiation flux.

The Penman-Monteith equation (Monteith 1965) provides an opportunity to make an estimate of potential evaporation that allows for both the influence of available energy and atmospheric humidity on evapotranspiration through vapor pressure deficit (VPD) and wind speed. 
TABLE 3. Regression statistics for global trends in reference crop evaporation and associated variables. Statistically significant trends in variables are indicated by slope values (in variable units per year) shown in bold. Minimum- and maximum-slope values refer to $95 \%$ confidence limits. Quantities are: Net rad $=$ net radiation, VPD $=$ vapor pressure deficit, Wind $=10-\mathrm{m}$ wind speed, Tair $=2-\mathrm{m}$ temperature, Neff $=$ Effective number of data points (allowing for lag-1 autocorrelation), and adjusted slope $P=$ probability of zero slope

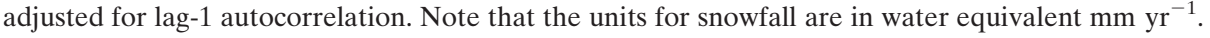

\begin{tabular}{|c|c|c|c|c|c|c|c|}
\hline Interval & Variable (units) & $\begin{array}{l}\text { Average } \\
\text { (units) }\end{array}$ & $\begin{array}{c}\text { Slope } \\
\text { (units } \mathrm{yr}^{-1} \text { ) }\end{array}$ & $\begin{array}{l}\text { Slope } \min \\
\text { (units } \mathrm{yr}^{-1} \text { ) }\end{array}$ & $\begin{array}{l}\text { Slope max } \\
\text { (units } \mathrm{yr}^{-1} \text { ) }\end{array}$ & Neff & $\begin{array}{c}\text { Adjusted } \\
\text { slope } P\end{array}$ \\
\hline $1901-57$ & $\operatorname{PET}_{\mathrm{rc}}\left(\mathrm{mm} \mathrm{yr}^{-1}\right)$ & 1021.11 & 0.0301 & -0.1324 & 0.1925 & 30 & $>0.200$ \\
\hline 1958-2001 & $\operatorname{PET}_{\mathrm{rc}}\left(\mathrm{mm} \mathrm{yr}^{-1}\right)$ & 1021.43 & $-\mathbf{0 . 5 1 1 6}$ & -0.7114 & -0.3119 & 9 & $<\mathbf{0 . 0 0 2}$ \\
\hline 1979-2001 & $\operatorname{PET}_{\mathrm{rc}}\left(\mathrm{mm} \mathrm{yr}^{-1}\right)$ & 1017.14 & -0.2157 & -0.6510 & 0.2195 & 18 & $>0.200$ \\
\hline $1901-57$ & Net $\operatorname{rad}\left(\mathrm{W} \mathrm{m}^{-2}\right)$ & 68.62 & -0.0112 & -0.0295 & 0.0072 & 56 & $>0.200$ \\
\hline 1958-2001 & Net $\operatorname{rad}\left(\mathrm{W} \mathrm{m}{ }^{-2}\right)$ & 67.88 & -0.0061 & -0.0279 & 0.0157 & 6 & $>0.200$ \\
\hline 1979-2001 & Net $\operatorname{rad}\left(\mathrm{W} \mathrm{m}{ }^{-2}\right)$ & 67.78 & -0.0815 & -0.1095 & -0.0534 & 6 & $<\mathbf{0 . 0 1 0}$ \\
\hline $1901-57$ & VPD $(\mathrm{kPa})$ & 0.9085 & 0.0003 & -0.0002 & 0.0008 & 40 & $>0.200$ \\
\hline 1958-2001 & $\mathrm{VPD}(\mathrm{kPa})$ & 0.9230 & -0.0006 & -0.0013 & 0.0001 & 5 & $<0.200$ \\
\hline 1979-2001 & VPD (kPa) & 0.9207 & 0.0014 & 0.0006 & 0.0220 & 11 & $<\mathbf{0 . 0 1 0}$ \\
\hline $1901-57$ & Wind $\left(\mathrm{m} \mathrm{s}^{-1}\right)$ & 2.12 & -0.0001 & -0.0005 & 0.0002 & 37 & $>0.200$ \\
\hline 1958-2001 & Wind $\left(\mathrm{m} \mathrm{s}^{-1}\right)$ & 2.14 & -0.0004 & -0.0009 & 0.0001 & 9 & $<0.200$ \\
\hline 1979-2001 & Wind $\left(\mathrm{m} \mathrm{s}^{-1}\right)$ & 2.11 & -0.0018 & -0.0025 & -0.0011 & 5 & $<0.001$ \\
\hline $1901-57$ & Tair $\left({ }^{\circ} \mathrm{C}\right)$ & 286.15 & 0.0069 & 0.0042 & 0.0097 & 15 & $<\mathbf{0 . 0 0 1}$ \\
\hline 1958-2001 & Tair $\left({ }^{\circ} \mathrm{C}\right)$ & 286.42 & 0.0164 & 0.0114 & 0.0214 & 10 & $<\mathbf{0 . 0 0 1}$ \\
\hline 1979-2001 & Tair $\left({ }^{\circ} \mathrm{C}\right)$ & 286.61 & 0.0254 & 0.0130 & 0.0377 & 11 & $<\mathbf{0 . 0 1 0}$ \\
\hline 1958-2001 & Rainfall $\left(\mathrm{mm} \mathrm{yr}^{-1}\right)$ & 814.98 & -0.0303 & -0.4695 & 0.4089 & 24 & $>0.200$ \\
\hline 1979-2001 & Rainfall (mm yr $\left.{ }^{-1}\right)$ & 812.38 & 0.5008 & -0.7797 & 1.7813 & 11 & $>0.200$ \\
\hline 1958-2001 & Snowfall $\left(\mathrm{mm} \mathrm{yr}^{-1}\right)$ & 58.47 & -0.0688 & $-\mathbf{0 . 1 1 7 2}$ & -0.0204 & 28 & $<\mathbf{0 . 0 1 0}$ \\
\hline 1979-2001 & Snowfall $\left(\mathrm{mm} \mathrm{yr}^{-1}\right)$ & 57.50 & -0.0638 & -0.1902 & 0.0627 & 23 & $>0.200$ \\
\hline 1958-2001 & Precipitation $\left(\mathrm{mm} \mathrm{yr}^{-1}\right)$ & 873.44 & -0.0991 & -0.5302 & 0.3320 & 25 & $>0.200$ \\
\hline 1979-2001 & Precipitation $\left(\mathrm{mm} \mathrm{yr}^{-1}\right)$ & 869.88 & 0.4370 & -0.8186 & 1.6926 & 11 & $>0.200$ \\
\hline
\end{tabular}

For this reason it is appropriate not only in humid but also in arid and semiarid climates. Shuttleworth (2006) and Shuttleworth et al. (2009) discussed the historical basis of the Penman-Monteith equation and practicalities of its calculation. Allen et al. (1998) specified a version of the Penman-Monteith equation that is now widely adopted as providing an estimate of evaporation from a "reference crop" (i.e., from a hypothetical, well-watered, 12-cm-high grass crop) by defining specific values of the resistances that appear in the Penman-Monteith equation. Thus, to obtain estimates of reference crop evaporation rate, hereafter referred to as $\mathrm{PET}_{\mathrm{rc}}$, the surface resistance $r_{s}$ is specified as being $70 \mathrm{~s} \mathrm{~m}^{-1}$ and the aerodynamic resistance $r_{a}\left(\right.$ in $\mathrm{s} \mathrm{m}^{-1}$ ) as

$$
r_{a}=208 / u_{2}
$$

where $u_{2}$ is the $2-\mathrm{m}$ wind speed (derived from the WFD $10-\mathrm{m}$ wind speed by multiplying by 0.749 ; Allen et al. 1998).

The vapor pressure deficit is given by

$$
\mathrm{VPD}=e_{\mathrm{sat}}-e,
$$

where $e$ is the vapor pressure and $e_{\text {sat }}$ the saturation vapor pressure. Using $r_{a}$ and $r_{s}$ specified for the reference crop, the version of the Penman-Monteith equation that provides an estimate of $\mathrm{PET}_{\mathrm{rc}}$ in $\mathrm{W} \mathrm{m}^{-2}$ (Shuttleworth et al. 2009) takes the form

$$
\mathrm{PET}_{\mathrm{rc}}=\frac{\Delta A\left(\rho C_{p} \mathrm{VPD}\right) / r_{a}}{\Delta+\gamma\left(1+r_{s} / r_{a}\right)}
$$

Equation (5) can be compared with Eq. (1).

Thus the calculation of $\mathrm{PET}_{\mathrm{rc}}$ requires use of six of the eight WFD forcing variables. The reference crop is defined to be always well watered and of limited extent, so that its presence does not significantly impact the value of the grid-average forcing variables, which are in part determined by the true area-average actual evaporation rate. If actual observations are used as forcing variables, the effect of area-average evaporation is presumably reflected in their values. However, if the forcing variables are in part derived from reanalysis data, it is implicitly assumed that the model used to calculate these (ERA-40) reanalysis data correctly calculates area-average actual evaporation, and its dependence on soil moisture. This assumption may not always be true in some regions and in some atmospheric conditions. In the following, $\mathrm{PET}_{\mathrm{rc}}$ and $\mathrm{PET}_{\mathrm{PT}}$ are compared as alternative estimates of potential evapotranspiration and have been converted to equivalent depth of evaporated water (in $\mathrm{mm}$ ) for ease of comparison with modeling results (e.g., Haddeland et al. 2011). Lu et al. (2005) investigated a selection of radiation-based or temperature-based PET methods, adopted where the full range of observed meteorological variables is not 
TABLE 4(a)-(h). Regression statistics for river basin trends in reference crop evaporation and associated variables. Statistically significant trends in variables are indicated by slope values (in variable units per year) shown in bold. Minimum- and maximum-slope values refer to $95 \%$ confidence limits. Quantities are: Net rad $=$ Net radiation, VPD $=$ vapor pressure deficit, wind $=10-\mathrm{m}$ wind speed, Tair $=$ 2-m temperature, Neff = effective number of data points (allowing for lag-1 autocorrelation), and adjusted slope $P=$ probability of zero

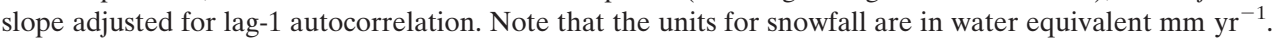

(a) Amazon River basin.

\begin{tabular}{|c|c|c|c|c|c|c|c|}
\hline Interval & Variable (units) & $\begin{array}{l}\text { Average } \\
\text { (units) }\end{array}$ & $\begin{array}{c}\text { Slope } \\
\left(\text { units } \mathrm{yr}^{-1} \text { ) }\right.\end{array}$ & $\begin{array}{l}\text { Slope-min } \\
\left({\text { units } \mathrm{yr}^{-1} \text { ) }}^{\text {Sin }}\right.\end{array}$ & $\begin{array}{l}\text { Slope-max } \\
\left(\text { units } \mathrm{yr}^{-1} \text { ) }\right.\end{array}$ & Neff & $\begin{array}{c}\text { Adjusted } \\
\text { slope } P\end{array}$ \\
\hline $1901-57$ & $\operatorname{PET}_{\mathrm{rc}}\left(\mathrm{mm} \mathrm{yr}^{-1}\right)$ & 1125.92 & -0.2414 & -0.5804 & 0.0977 & 44 & $<0.200$ \\
\hline 1958-2001 & $\operatorname{PET}_{\mathrm{rc}}\left(\mathrm{mm} \mathrm{yr}^{-1}\right)$ & 1108.09 & $-\mathbf{1 . 8 8 5 4}$ & -2.5657 & -1.2050 & 5 & $<\mathbf{0 . 0 2 0}$ \\
\hline 1979-2001 & $\operatorname{PET}_{\mathrm{rc}}\left(\mathrm{mm} \mathrm{yr}^{-1}\right)$ & 1092.60 & -0.5602 & -1.6996 & 0.5791 & 19 & $>0.200$ \\
\hline $1901-57$ & $\operatorname{PET}_{\mathrm{PT}}\left(\mathrm{mm} \mathrm{yr}^{-1}\right)$ & 1269.64 & -0.2635 & -1.1746 & 0.6475 & 46 & $>0.200$ \\
\hline 1958-2001 & $\operatorname{PET}_{\mathrm{PT}}\left(\mathrm{mm} \mathrm{yr}^{-1}\right)$ & 1240.99 & 1.3643 & 0.5677 & 2.1608 & 8 & $<\mathbf{0 . 0 2 0}$ \\
\hline 1979-2001 & $\operatorname{PET}_{\mathrm{PT}}\left(\mathrm{mm} \mathrm{yr}^{-1}\right)$ & 1254.50 & -0.7086 & -1.9611 & 0.5440 & 18 & $>0.200$ \\
\hline $1901-57$ & Net $\operatorname{rad}\left(\mathrm{W} \mathrm{m}{ }^{-2}\right)$ & 104.82 & -0.0222 & -0.0958 & 0.0519 & 45 & $>0.200$ \\
\hline 1958-2001 & Net $\operatorname{rad}\left(\mathrm{W} \mathrm{m}^{-2}\right)$ & 102.31 & 0.1035 & 0.0361 & 0.1709 & 8 & $<\mathbf{0 . 0 5 0}$ \\
\hline 1979-2001 & Net $\operatorname{rad}\left(\mathrm{W} \mathrm{m}^{-2}\right)$ & 103.31 & -0.0855 & -0.1769 & 0.0059 & 15 & $<0.100$ \\
\hline $1901-57$ & $\mathrm{VPD}(\mathrm{kPa})$ & 0.7943 & -0.0001 & -0.0030 & 0.0029 & 49 & $>0.200$ \\
\hline $1958-2001$ & VPD $(\mathrm{kPa})$ & 0.7651 & -0.0094 & -0.0132 & $-\mathbf{0 . 0 0 5 7}$ & 4 & $<\mathbf{0 . 0 5 0}$ \\
\hline 1979-2001 & VPD (kPa) & 0.6846 & 0.0015 & -0.0004 & 0.0034 & 20 & $<0.200$ \\
\hline $1901-57$ & Wind $\left(\mathrm{m} \mathrm{s}^{-1}\right)$ & 0.93 & -0.0001 & -0.0006 & 0.0004 & 46 & $>0.200$ \\
\hline 1958-2001 & Wind $\left(\mathrm{m} \mathrm{s}^{-1}\right)$ & 0.93 & -0.0017 & -0.0022 & -0.0011 & 12 & $<0.001$ \\
\hline 1979-2001 & Wind $\left(\mathrm{m} \mathrm{s}^{-1}\right)$ & 0.91 & -0.0026 & -0.0038 & -0.0015 & 10 & $<\mathbf{0 . 0 0 2}$ \\
\hline $1958-2001$ & Rainfall $\left(\mathrm{mm} \mathrm{yr}^{-1}\right)$ & 2256.18 & 0.4170 & -2.2557 & 3.0896 & 28 & $>0.200$ \\
\hline 1979-2001 & Rainfall $\left(\mathrm{mm} \mathrm{yr}^{-1}\right)$ & 2244.23 & 0.8602 & -6.6545 & 8.3748 & 23 & $>0.200$ \\
\hline 1958-2001 & Snowfall $\left(\mathrm{mm} \mathrm{yr}^{-1}\right)$ & 0.24 & 0.0004 & -0.0016 & 0.0024 & 44 & $>0.200$ \\
\hline 1979-2001 & Snowfall $\left(\mathrm{mm} \mathrm{yr}^{-1}\right)$ & 0.24 & -0.0019 & -0.0081 & 0.0044 & 23 & $>0.200$ \\
\hline
\end{tabular}

(b) Congo River basin.

\begin{tabular}{llcrrrr}
\hline Interval & Variable (units) & $\begin{array}{c}\text { Average } \\
\text { (units) }\end{array}$ & $\begin{array}{c}\text { Slope } \\
\left(\text { units yr }^{-1}\right)\end{array}$ & $\begin{array}{c}\text { Slope-min } \\
\left(\text { units yr }^{-1}\right)\end{array}$ & $\begin{array}{r}\text { Slope-max } \\
\text { units yr }^{-1} \text { ) }\end{array}$ & $\begin{array}{r}\text { Adjusted } \\
\text { Neff }\end{array}$ \\
\hline slope $P$
\end{tabular}

(c) Orange River basin.

\begin{tabular}{|c|c|c|c|c|c|c|c|}
\hline Interval & Variable (units) & $\begin{array}{l}\text { Average } \\
\text { (units) }\end{array}$ & $\begin{array}{c}\text { Slope } \\
\text { (units } \mathrm{yr}^{-1} \text { ) }\end{array}$ & $\begin{array}{l}\text { Slope-min } \\
\text { (units } \mathrm{yr}^{-1} \text { ) }\end{array}$ & $\begin{array}{l}\text { Slope-max } \\
\left(\text { units } \mathrm{yr}^{-1} \text { ) }\right.\end{array}$ & Neff & $\begin{array}{c}\text { Adjusted } \\
\text { slope } P\end{array}$ \\
\hline $1901-57$ & $\operatorname{PET}_{\mathrm{rc}}\left(\mathrm{mm} \mathrm{yr}^{-1}\right)$ & 1586.19 & 1.2338 & 0.3431 & 2.1244 & 31 & $<\mathbf{0 . 0 1 0}$ \\
\hline 1958-2001 & $\operatorname{PET}_{\mathrm{rc}}\left(\mathrm{mm} \mathrm{yr}^{-1}\right)$ & 1604.15 & 0.6463 & -0.8474 & 2.1401 & 28 & $>0.200$ \\
\hline 1979-2001 & $\mathrm{PET}_{\mathrm{rc}}\left(\mathrm{mm} \mathrm{yr}^{-1}\right)$ & 1623.47 & -2.3898 & -5.8193 & 1.0396 & 15 & $<0.200$ \\
\hline $1901-57$ & $\mathrm{PET}_{\mathrm{PT}}\left(\mathrm{mm} \mathrm{yr}^{-1}\right)$ & 1114.63 & 0.2471 & -0.4026 & 0.8969 & 57 & $>0.200$ \\
\hline 1958-2001 & $\operatorname{PET}_{\mathrm{PT}}\left(\mathrm{mm} \mathrm{yr}^{-1}\right)$ & 1123.40 & 1.1023 & 0.4501 & 1.7545 & 9 & $<\mathbf{0 . 0 2 0}$ \\
\hline 1979-2001 & $\operatorname{PET}_{\mathrm{PT}}\left(\mathrm{mm} \mathrm{yr}^{-1}\right)$ & 1131.46 & 0.7341 & -0.5372 & 2.0053 & 10 & $>0.200$ \\
\hline $1901-57$ & Net $\mathrm{rad}\left(\mathrm{W} \mathrm{m}{ }^{-2}\right)$ & 96.75 & -0.0030 & -0.0585 & 0.0525 & 57 & $>0.200$ \\
\hline
\end{tabular}


TABLE 4. (Continued)

\begin{tabular}{|c|c|c|c|c|c|c|c|}
\hline \multicolumn{8}{|c|}{ (c) Orange River basin. } \\
\hline Interval & Variable (units) & $\begin{array}{l}\text { Average } \\
\text { (units) }\end{array}$ & $\begin{array}{c}\text { Slope } \\
\text { (units } \mathrm{yr}^{-1} \text { ) }\end{array}$ & $\begin{array}{l}\text { Slope-min } \\
\text { (units } \mathrm{yr}^{-1} \text { ) }\end{array}$ & $\begin{array}{l}\text { Slope-max } \\
\text { (units } \mathrm{yr}^{-1} \text { ) }\end{array}$ & Neff & $\begin{array}{l}\text { Adjusted } \\
\text { slope } P\end{array}$ \\
\hline 1958-2001 & Net $\mathrm{rad}\left(\mathrm{W} \mathrm{m}^{-2}\right)$ & 96.79 & 0.0805 & 0.0147 & 0.1464 & 7 & $<\mathbf{0 . 1 0 0}$ \\
\hline $1979-2001$ & Net $\operatorname{rad}\left(\mathrm{W} \mathrm{m}^{-2}\right)$ & 97.17 & 0.0648 & -0.0629 & 0.1926 & 8 & $>0.200$ \\
\hline $1901-57$ & $\operatorname{VPD}(\mathrm{kPa})$ & 1.4479 & 0.0021 & 0.0004 & 0.0038 & 35 & $<\mathbf{0 . 0 5 0}$ \\
\hline 1958-2001 & $\mathrm{VPD}(\mathrm{kPa})$ & 1.4879 & 0.0013 & -0.0018 & 0.0043 & 18 & $>0.200$ \\
\hline $1979-2001$ & $\operatorname{VPD}(\mathrm{kPa})$ & 1.5289 & -0.0040 & -0.0108 & 0.0029 & 14 & $>0.200$ \\
\hline $1901-57$ & Wind $\left(\mathrm{m} \mathrm{s}^{-1}\right)$ & 2.20 & 0.0006 & -0.0003 & 0.0014 & 57 & $<0.200$ \\
\hline $1958-2001$ & Wind $\left(\mathrm{m} \mathrm{s}^{-1}\right)$ & 2.20 & 0.0002 & -0.0012 & 0.0015 & 26 & $>0.200$ \\
\hline 1979-2001 & Wind $\left(\mathrm{m} \mathrm{s}^{-1}\right)$ & 2.21 & -0.0037 & -0.0075 & 0.0001 & 10 & $<0.100$ \\
\hline $1958-2001$ & Rainfall $\left(\mathrm{mm} \mathrm{yr}^{-1}\right)$ & 346.47 & 0.8493 & -1.3792 & 3.0779 & 27 & $>0.200$ \\
\hline 1979-2001 & Rainfall $\left(\mathrm{mm} \mathrm{yr}^{-1}\right)$ & 337.84 & 3.8769 & -1.0266 & 8.7804 & 22 & $<0.200$ \\
\hline 1958-2001 & Snowfall $\left(\mathrm{mm} \mathrm{yr}^{-1}\right)$ & 0.12 & -0.0040 & -0.0106 & 0.0027 & 44 & $>0.200$ \\
\hline 1979-2001 & Snowfall $\left(\mathrm{mm} \mathrm{yr}^{-1}\right)$ & 0.10 & -0.0024 & -0.0130 & 0.0083 & 16 & $>0.200$ \\
\hline
\end{tabular}

(d) Murray-Darling River basin.

\begin{tabular}{|c|c|c|c|c|c|c|c|}
\hline Interval & Variable (units) & $\begin{array}{l}\text { Average } \\
\text { (units) }\end{array}$ & $\begin{array}{c}\text { Slope } \\
\text { (units } \mathrm{yr}^{-1} \text { ) }\end{array}$ & $\begin{array}{l}\text { Slope-min } \\
\text { (units } \mathrm{yr}^{-1} \text { ) }\end{array}$ & $\begin{array}{l}\text { Slope-max } \\
\text { (units } \mathrm{yr}^{-1} \text { ) }\end{array}$ & Neff & $\begin{array}{c}\text { Adjusted } \\
\text { Slope P }\end{array}$ \\
\hline $1901-57$ & $\operatorname{PET}_{\mathrm{rc}}\left(\mathrm{mm} \mathrm{yr}^{-1}\right)$ & 1429.10 & -1.5615 & -2.7132 & -0.4099 & 31 & $<\mathbf{0 . 0 2 0}$ \\
\hline 1958-2001 & $\operatorname{PET}_{\mathrm{rc}}\left(\mathrm{mm} \mathrm{yr}^{-1}\right)$ & 1449.35 & -3.6782 & -5.0245 & -2.3319 & 19 & $<0.001$ \\
\hline $1979-2001$ & $\operatorname{PET}_{\mathrm{rc}}\left(\mathrm{mm} \mathrm{yr}^{-1}\right)$ & 1415.69 & $-\mathbf{5 . 4 5 8 5}$ & -9.2862 & -0.1631 & 12 & $<\mathbf{0 . 0 2 0}$ \\
\hline $1901-57$ & $\mathrm{PET}_{\mathrm{PT}}\left(\mathrm{mm} \mathrm{yr}^{-1}\right)$ & 959.10 & -1.0514 & -1.9348 & -0.1680 & 52 & $<\mathbf{0 . 0 5 0}$ \\
\hline $1958-2001$ & $\operatorname{PET}_{\mathrm{PT}}\left(\mathrm{mm} \mathrm{yr}^{-1}\right)$ & 997.21 & 2.5360 & 1.8242 & 3.2479 & 11 & $<\mathbf{0 . 0 0 1}$ \\
\hline 1979-2001 & $\operatorname{PET}_{\mathrm{PT}}\left(\mathrm{mm} \mathrm{yr}^{-1}\right)$ & 1028.81 & 0.6654 & -1.2824 & 2.6132 & 23 & $>0.200$ \\
\hline $1901-57$ & Net $\operatorname{rad}\left(\mathrm{W} \mathrm{m}{ }^{-2}\right)$ & 85.33 & -0.0714 & -0.1468 & 0.0039 & 56 & $<0.100$ \\
\hline $1958-2001$ & Net $\operatorname{rad}\left(\mathrm{W} \mathrm{m}^{-2}\right)$ & 88.69 & 0.2188 & 0.1617 & 0.2758 & 11 & $<\mathbf{0 . 0 0 1}$ \\
\hline 1979-2001 & Net $\operatorname{rad}\left(\mathrm{W} \mathrm{m}{ }^{-2}\right)$ & 91.30 & 0.1054 & -0.0547 & 0.2655 & 23 & $<0.200$ \\
\hline $1901-57$ & $\mathrm{VPD}(\mathrm{kPa})$ & 1.2676 & -0.0019 & -0.0038 & 0.0000 & 32 & $<0.100$ \\
\hline $1958-2001$ & VPD $(\mathrm{kPa})$ & 1.2665 & -0.0071 & -0.0091 & -0.0051 & 11 & $<0.001$ \\
\hline 1979-2001 & VPD (kPa) & 1.1957 & -0.0087 & -0.0144 & $-\mathbf{0 . 0 0 3 0}$ & 10 & $<\mathbf{0 . 0 2 0}$ \\
\hline $1901-57$ & Wind $\left(\mathrm{m} \mathrm{s}^{-1}\right)$ & 2.38 & 0.0000 & -0.0010 & 0.0009 & 57 & $>0.200$ \\
\hline 1958-2001 & Wind $\left(\mathrm{m} \mathrm{s}^{-1}\right)$ & 2.38 & -0.0008 & -0.0023 & 0.0006 & 19 & $>0.200$ \\
\hline 1979-2001 & Wind $\left(\mathrm{m} \mathrm{s}^{-1}\right)$ & 2.38 & -0.0053 & -0.0094 & -0.0013 & 6 & $<0.100$ \\
\hline 1958-2001 & Rainfall (mm yr $\left.{ }^{-1}\right)$ & 501.49 & 0.9950 & -1.5083 & 3.4984 & 44 & $>0.200$ \\
\hline 1979-2001 & Rainfall $\left(\mathrm{mm} \mathrm{yr}^{-1}\right)$ & 497.89 & 4.2298 & -2.1663 & 10.6260 & 23 & $<0.200$ \\
\hline 1958-2001 & Snowfall $\left(\mathrm{mm} \mathrm{yr}^{-1}\right)$ & 0.12 & -0.0040 & -0.0106 & 0.0027 & 44 & $>0.200$ \\
\hline 1979-2001 & Snowfall $\left(\mathrm{mm} \mathrm{yr}^{-1}\right)$ & 0.00 & -0.0060 & -0.0012 & 0.0000 & 4 & $>0.200$ \\
\hline
\end{tabular}

(e) Mackenzie River basin.

\begin{tabular}{|c|c|c|c|c|c|c|c|}
\hline Interval & Variable (units) & $\begin{array}{l}\text { Average } \\
\text { (units) }\end{array}$ & $\begin{array}{c}\text { Slope } \\
\text { (units } \mathrm{yr}^{-1} \text { ) }\end{array}$ & 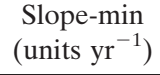 & 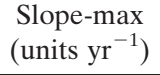 & Neff & $\begin{array}{l}\text { Adjusted } \\
\text { slope } P\end{array}$ \\
\hline 1901-57 & $\operatorname{PET}_{\mathrm{rc}}\left(\mathrm{mm} \mathrm{yr}^{-1}\right)$ & 369.86 & 0.2074 & 0.0009 & 0.4139 & 51 & $<\mathbf{0 . 0 5 0}$ \\
\hline $1958-2001$ & $\operatorname{PET}_{\mathrm{rc}}\left(\mathrm{mm} \mathrm{yr}^{-1}\right)$ & 406.68 & 0.0561 & -0.3112 & 0.4233 & 32 & $>0.200$ \\
\hline 1979-2001 & $\operatorname{PET}_{\mathrm{rc}}\left(\mathrm{mm} \mathrm{yr}^{-1}\right)$ & 408.07 & 0.5876 & -0.4818 & 1.5771 & 17 & $>0.200$ \\
\hline $1901-57$ & $\operatorname{PET}_{\mathrm{PT}}\left(\mathrm{mm} \mathrm{yr}^{-1}\right)$ & 331.55 & 0.1970 & -0.0538 & 0.4478 & 49 & $<0.200$ \\
\hline $1958-2001$ & $\operatorname{PET}_{\mathrm{PT}}\left(\mathrm{mm} \mathrm{yr}^{-1}\right)$ & 340.08 & 0.6888 & 0.3724 & 1.0051 & 12 & $<0.002$ \\
\hline 1979-2001 & $\operatorname{PET}_{\mathrm{PT}}\left(\mathrm{mm} \mathrm{yr}^{-1}\right)$ & 345.62 & 0.3891 & -0.3251 & 1.1034 & 22 & $>0.200$ \\
\hline $1901-57$ & Net $\operatorname{rad}\left(\mathrm{W} \mathrm{m}^{-2}\right)$ & 32.67 & 0.0011 & -0.0350 & 0.0373 & 56 & $>0.200$ \\
\hline 1958-2001 & Net $\operatorname{rad}\left(\mathrm{W} \mathrm{m}^{-2}\right)$ & 32.98 & 0.0608 & 0.0223 & 0.0993 & 4 & $<0.100$ \\
\hline 1979-2001 & Net $\operatorname{rad}\left(\mathrm{W} \mathrm{m}{ }^{-2}\right)$ & 33.37 & 0.0052 & -0.0529 & 0.0633 & 9 & $>0.200$ \\
\hline $1901-57$ & $\mathrm{VPD}(\mathrm{kPa})$ & 0.2643 & 0.0002 & -0.0001 & 0.0006 & 57 & $>0.200$ \\
\hline 1958-2001 & VPD $(\mathrm{kPa})$ & 0.2724 & -0.0004 & -0.0010 & 0.0002 & 19 & $<0.200$ \\
\hline 1979-2001 & VPD (kPa) & 0.2717 & 0.0004 & -0.0010 & 0.0018 & 18 & $>0.200$ \\
\hline $1901-57$ & Wind $\left(\mathrm{m} \mathrm{s}^{-1}\right)$ & 1.69 & 0.0000 & -0.0006 & 0.0005 & 49 & $>0.200$ \\
\hline 1958-2001 & Wind $\left(\mathrm{m} \mathrm{s}^{-1}\right)$ & 1.69 & -0.0007 & -0.0016 & 0.0001 & 22 & $<0.200$ \\
\hline 1979-2001 & Wind $\left(\mathrm{m} \mathrm{s}^{-1}\right)$ & 1.68 & 0.0003 & -0.0021 & 0.0027 & 12 & $>0.200$ \\
\hline 1958-2001 & Rainfall $\left(\mathrm{mm} \mathrm{yr}^{-1}\right)$ & 305.60 & 0.4356 & -0.2656 & 1.1368 & 44 & $>0.200$ \\
\hline 1979-2001 & Rainfall $\left(\mathrm{mm} \mathrm{yr}^{-1}\right)$ & 309.42 & 0.1876 & -1.9114 & 2.2865 & 23 & $>0.200$ \\
\hline 1958-2001 & Snowfall $\left(\mathrm{mm} \mathrm{yr}^{-1}\right)$ & 142.10 & -0.7210 & -1.1773 & -0.2646 & 18 & $<\mathbf{0 . 0 1 0}$ \\
\hline
\end{tabular}


TABLE 4. (Continued)

(e) Mackenzie River basin.

\begin{tabular}{clcccccr}
\hline Interval & \multicolumn{1}{c}{ Variable (units) } & $\begin{array}{c}\text { Average } \\
\text { (units) }\end{array}$ & $\begin{array}{c}\text { Slope } \\
\left(\text { units yr }^{-1}\right)\end{array}$ & $\begin{array}{c}\text { Slope-min } \\
\left(\text { units yr }^{-1}\right)\end{array}$ & $\begin{array}{c}\text { Slope-max } \\
\left(\text { units yr }^{-1}\right)\end{array}$ & $\begin{array}{c}\text { Neff } \\
\text { Adjusted } \\
\text { slope } P\end{array}$ \\
\hline 1979-2001 & Snowfall $\left(\mathrm{mm} \mathrm{yr}^{-1}\right)$ & 135.52 & -0.5198 & -1.6767 & 0.6371 & 16 & $>0.200$ \\
1958-2001 & Precipitation $\left(\mathrm{mm} \mathrm{yr}^{-1}\right)$ & 447.70 & -0.2854 & -1.1460 & 0.5753 & 39 & $>0.200$ \\
1979-2001 & Precipitation $\left(\mathrm{mm} \mathrm{yr}^{-1}\right)$ & 444.93 & -0.3322 & -2.9133 & 2.2488 & 23 & $>0.200$
\end{tabular}

(f) Lena River basin.

\begin{tabular}{|c|c|c|c|c|c|c|c|}
\hline Interval & Variable (units) & $\begin{array}{c}\text { Average } \\
\text { (units) }\end{array}$ & $\begin{array}{c}\text { Slope } \\
{\text { (units } \mathrm{yr}^{-1} \text { ) }}^{\text {) }}\end{array}$ & 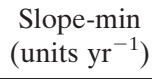 & 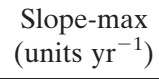 & Neff & $\begin{array}{c}\text { Adjustec } \\
\text { slope } P\end{array}$ \\
\hline $1901-57$ & $\mathrm{PET}_{\mathrm{rc}}\left(\mathrm{mm} \mathrm{yr}^{-1}\right)$ & 363.47 & 0.1315 & -0.0722 & 0.3353 & 49 & $>0.200$ \\
\hline 1958-2001 & $\mathrm{PET}_{\mathrm{rc}}\left(\mathrm{mm} \mathrm{yr}{ }^{-1}\right)$ & 366.70 & -0.0454 & -0.3089 & 0.2181 & 36 & $>0.200$ \\
\hline 1979-2001 & $\operatorname{PET}_{\mathrm{rc}}\left(\mathrm{mm} \mathrm{yr}^{-1}\right)$ & 366.11 & 0.5366 & -0.0751 & 1.1483 & 23 & $<0.100$ \\
\hline $1901-57$ & $\operatorname{PET}_{\mathrm{PT}}\left(\mathrm{mm} \mathrm{yr}^{-1}\right)$ & 312.82 & 0.1505 & -0.0467 & 0.3478 & 43 & $<0.200$ \\
\hline 1958-2001 & $\operatorname{PET}_{\mathrm{PT}}\left(\mathrm{mm} \mathrm{yr}^{-1}\right)$ & 313.48 & 0.2437 & 0.0428 & 0.4446 & 21 & $<0.050$ \\
\hline 1979-2001 & $\operatorname{PET}_{\mathrm{PT}}\left(\mathrm{mm} \mathrm{yr}^{-1}\right)$ & 314.73 & 0.4203 & -0.1461 & 0.9867 & 12 & $<0.200$ \\
\hline $1901-57$ & Net $\mathrm{rad}\left(\mathrm{W} \mathrm{m}^{-2}\right)$ & 29.05 & 0.0137 & -0.0151 & 0.0424 & 39 & $>0.200$ \\
\hline 1958-2001 & Net $\operatorname{rad}\left(\mathrm{W} \mathrm{m}^{-2}\right)$ & 28.65 & 0.0072 & -0.0233 & 0.0377 & 23 & $>0.200$ \\
\hline 1979-2001 & Net $\operatorname{rad}\left(\mathrm{W} \mathrm{m}^{-2}\right)$ & 28.65 & -0.0658 & -0.1428 & 0.0111 & 20 & $<0.100$ \\
\hline $1901-57$ & VPD $(\mathrm{kPa})$ & 0.2404 & 0.0001 & -0.0002 & 0.0004 & 49 & $>0.200$ \\
\hline 1958-2001 & VPD (kPa) & 0.2443 & 0.0000 & -0.0005 & 0.0004 & 22 & $>0.200$ \\
\hline 1979-2001 & VPD (kPa) & 0.2453 & 0.0010 & -0.0002 & 0.0021 & 16 & $<0.200$ \\
\hline $1901-57$ & Wind $\left(\mathrm{m} \mathrm{s}^{-1}\right)$ & 1.69 & -0.0002 & -0.0009 & 0.0005 & 51 & $>0.200$ \\
\hline 1958-2001 & Wind $\left(\mathrm{m} \mathrm{s}^{-1}\right)$ & 1.69 & -0.0019 & -0.0029 & -0.0010 & 13 & $<0.020$ \\
\hline 1979-2001 & Wind $\left(\mathrm{m} \mathrm{s}^{-1}\right)$ & 1.66 & -0.0019 & -0.0038 & 0.0000 & 14 & $<0.100$ \\
\hline 1958-2001 & Rainfall $\left(\mathrm{mm} \mathrm{yr}^{-1}\right)$ & 259.68 & -0.1461 & -0.8585 & 0.5662 & 24 & $>0.200$ \\
\hline 1979-2001 & Rainfall $\left(\mathrm{mm} \mathrm{yr}^{-1}\right)$ & 255.52 & 0.8346 & -1.3203 & 2.9894 & 11 & $>0.200$ \\
\hline 1958-2001 & Snowfall $\left(\mathrm{mm} \mathrm{yr}^{-1}\right)$ & 132.34 & -0.1109 & -0.3844 & 0.1627 & 44 & $>0.200$ \\
\hline 1979-2001 & Snowfall $\left(\mathrm{mm} \mathrm{yr}^{-1}\right)$ & 131.41 & 0.2453 & -0.5521 & 1.0427 & 23 & $>0.200$ \\
\hline 1958-2001 & Precipitation $\left(\mathrm{mm} \mathrm{yr}^{-1}\right)$ & 392.02 & -0.2570 & -1.0123 & 0.4984 & 24 & $>0.200$ \\
\hline 1979-2001 & Precipitation $\left(\mathrm{mm} \mathrm{yr}^{-1}\right)$ & 386.93 & 1.0798 & -1.1278 & 3.2874 & 7 & $>0.200$ \\
\hline
\end{tabular}

(g) Niger River basin.

\begin{tabular}{|c|c|c|c|c|c|c|c|}
\hline Interval & Variable (units) & $\begin{array}{l}\text { Average } \\
\text { (units) }\end{array}$ & 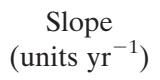 & 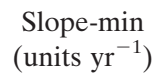 & 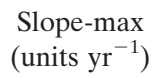 & Neff & $\begin{array}{l}\text { Adjusted } \\
\text { slope } P\end{array}$ \\
\hline $1901-57$ & $\operatorname{PET}_{\mathrm{rc}}\left(\mathrm{mm} \mathrm{yr}^{-1}\right)$ & 1667.93 & 0.1785 & -0.4682 & 0.8253 & 55 & $>0.200$ \\
\hline 1958-2001 & $\operatorname{PET}_{\mathrm{rc}}\left(\mathrm{mm} \mathrm{yr}^{-1}\right)$ & 1659.01 & 1.8835 & 0.9848 & 2.7822 & 13 & $<\mathbf{0 . 0 0 2}$ \\
\hline 1979-2001 & $\operatorname{PET}_{\mathrm{rc}}\left(\mathrm{mm} \mathrm{yr}^{-1}\right)$ & 1685.63 & -0.6072 & -2.9829 & 1.7685 & 11 & $>0.200$ \\
\hline $1901-57$ & $\operatorname{PET}_{\mathrm{PT}}\left(\mathrm{mm} \mathrm{yr}^{-1}\right)$ & 1004.12 & -0.2402 & -0.8010 & 0.3207 & 46 & $>0.200$ \\
\hline 1958-2001 & $\operatorname{PET}_{\mathrm{PT}}\left(\mathrm{mm} \mathrm{yr}^{-1}\right)$ & 989.89 & -1.7656 & -2.5145 & -1.0166 & 13 & $<0.001$ \\
\hline 1979-2001 & $\operatorname{PET}_{\mathrm{PT}}\left(\mathrm{mm} \mathrm{yr}^{-1}\right)$ & 973.49 & -0.8341 & -2.3956 & 0.7273 & 11 & $>0.200$ \\
\hline $1901-57$ & Net $\mathrm{rad}\left(\mathrm{W} \mathrm{m}{ }^{-2}\right)$ & 79.18 & -0.0216 & -0.0649 & 0.0217 & 46 & $>0.200$ \\
\hline 1958-2001 & Net $\operatorname{rad}\left(\mathrm{W} \mathrm{m}{ }^{-2}\right)$ & 77.91 & $-\mathbf{0 . 1 5 2 7}$ & -0.2102 & -0.0951 & 11 & $<\mathbf{0 . 0 0 1}$ \\
\hline 1979-2001 & Net $\operatorname{rad}\left(\mathrm{W} \mathrm{m}{ }^{-2}\right)$ & 76.45 & -0.0696 & -0.1910 & 0.0517 & 12 & $>0.200$ \\
\hline $1901-57$ & $\mathrm{VPD}(\mathrm{kPa})$ & 2.1796 & 0.0011 & -0.0006 & 0.0027 & 43 & $<0.200$ \\
\hline 1958-2001 & $\mathrm{VPD}(\mathrm{kPa})$ & 2.1975 & 0.0067 & 0.0047 & 0.0087 & 12 & $<\mathbf{0 . 0 0 1}$ \\
\hline 1979-2001 & VPD (kPa) & 2.2750 & 0.0046 & -0.0008 & 0.0099 & 13 & $<0.200$ \\
\hline $1901-57$ & Wind $\left(\mathrm{m} \mathrm{s}^{-1}\right)$ & 1.97 & -0.0002 & -0.0012 & 0.0009 & 37 & $>0.200$ \\
\hline 1958-2001 & Wind $\left(\mathrm{m} \mathrm{s}^{-1}\right)$ & 1.97 & 0.0013 & -0.0002 & 0.0028 & 10 & $<0.200$ \\
\hline $1979-2001$ & Wind $\left(\mathrm{m} \mathrm{s}^{-1}\right)$ & 1.99 & -0.0060 & -0.0092 & -0.0028 & 6 & $<\mathbf{0 . 0 2 0}$ \\
\hline $1958-2001$ & Rainfall $\left(\mathrm{mm} \mathrm{yr}^{-1}\right)$ & 809.79 & -2.3978 & -4.0349 & -0.7607 & 18 & $<\mathbf{0 . 0 1 0}$ \\
\hline 1979-2001 & Rainfall $\left(\mathrm{mm} \mathrm{yr}^{-1}\right)$ & 777.35 & 3.3915 & -0.8515 & 7.6346 & 15 & $<0.200$ \\
\hline
\end{tabular}

(h) Ganges-Brahmaputra River basin.

\begin{tabular}{|c|c|c|c|c|c|c|c|}
\hline Interval & Variable (units) & $\begin{array}{c}\text { Average } \\
\text { (units) }\end{array}$ & $\begin{array}{c}\text { Slope } \\
\text { (units } \mathrm{yr}^{-1} \text { ) }\end{array}$ & 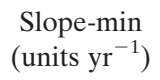 & 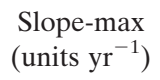 & Neff & $\begin{array}{l}\text { Adjusted } \\
\text { slope } P\end{array}$ \\
\hline $1901-57$ & $\operatorname{PET}_{\mathrm{rc}}\left(\mathrm{mm} \mathrm{yr}^{-1}\right)$ & 889.32 & 0.0368 & -0.3372 & 0.4109 & 32 & $>0.200$ \\
\hline 1958-2001 & $\operatorname{PET}_{\mathrm{rc}}\left(\mathrm{mm} \mathrm{yr}^{-1}\right)$ & 869.68 & -2.2561 & -2.7595 & -1.7528 & 7 & $<\mathbf{0 . 0 0 1}$ \\
\hline 1979-2001 & $\operatorname{PET}_{\mathrm{rc}}\left(\mathrm{mm} \mathrm{yr}^{-1}\right)$ & 843.63 & -1.8416 & -2.7902 & -0.8930 & 8 & $<\mathbf{0 . 0 1 0}$ \\
\hline
\end{tabular}


TABLE 4. (Continued)

\begin{tabular}{|c|c|c|c|c|c|c|c|}
\hline \multicolumn{8}{|c|}{ (h) Ganges-Brahmaputra River basin. } \\
\hline Interval & Variable (units) & $\begin{array}{l}\text { Average } \\
\text { (units) }\end{array}$ & $\begin{array}{c}\text { Slope } \\
\left(\text { units } \mathrm{yr}^{-1} \text { ) }\right.\end{array}$ & $\begin{array}{l}\text { Slope-min } \\
\text { (units } \mathrm{yr}^{-1} \text { ) }\end{array}$ & $\begin{array}{l}\text { Slope-max } \\
\left(\text { units } \mathrm{yr}^{-1} \text { ) }\right.\end{array}$ & Neff & $\begin{array}{c}\text { Adjusted } \\
\text { slope } P\end{array}$ \\
\hline $1901-57$ & $\operatorname{PET}_{\mathrm{PT}}\left(\mathrm{mm} \mathrm{yr}^{-1}\right)$ & 798.70 & 0.0968 & -0.2996 & 0.4931 & 41 & $>0.200$ \\
\hline 1958-2001 & $\mathrm{PET}_{\mathrm{PT}}\left(\mathrm{mm} \mathrm{yr}^{-1}\right)$ & 767.99 & -1.2596 & -1.7339 & $-\mathbf{0 . 7 8 5 2}$ & 10 & $<\mathbf{0 . 0 0 1}$ \\
\hline 1979-2001 & $\operatorname{PET}_{\mathrm{PT}}\left(\mathrm{mm} \mathrm{yr}^{-1}\right)$ & 752.00 & -0.8951 & -2.0125 & 0.2223 & 15 & $<0.200$ \\
\hline $1901-57$ & Net $\mathrm{rad}\left(\mathrm{W} \mathrm{m}{ }^{-2}\right)$ & 69.75 & -0.0008 & -0.0357 & 0.0340 & 41 & $>0.200$ \\
\hline $1958-2001$ & Net $\mathrm{rad}\left(\mathrm{W} \mathrm{m}{ }^{-2}\right)$ & 67.01 & $-\mathbf{0 . 1 2 3 0}$ & -0.1683 & -0.0778 & 9 & $<0.001$ \\
\hline 1979-2001 & Net $\operatorname{rad}\left(\mathrm{W} \mathrm{m}^{-2}\right)$ & 65.45 & -0.1041 & -0.2159 & 0.0078 & 12 & $<0.100$ \\
\hline $1901-57$ & VPD $(\mathrm{kPa})$ & 0.9467 & 0.0003 & -0.0009 & 0.0016 & 44 & $>0.200$ \\
\hline 1958-2001 & VPD $(\mathrm{kPa})$ & 0.9570 & -0.0032 & -0.0050 & -0.0014 & 17 & $<0.001$ \\
\hline 1979-2001 & VPD $(\mathrm{kPa})$ & 0.9281 & -0.0035 & -0.0071 & 0.0001 & 14 & $<0.100$ \\
\hline $1901-57$ & Wind $\left(\mathrm{m} \mathrm{s}^{-1}\right)$ & 1.12 & -0.0003 & -0.0009 & 0.0003 & 56 & $>0.200$ \\
\hline 1958-2001 & Wind $\left(\mathrm{m} \mathrm{s}^{-1}\right)$ & 1.12 & 0.0000 & -0.0009 & 0.0008 & 11 & $>0.200$ \\
\hline 1979-2001 & Wind $\left(\mathrm{m} \mathrm{s}^{-1}\right)$ & 1.11 & 0.0004 & -0.0012 & 0.0020 & 15 & $>0.200$ \\
\hline $1958-2001$ & Rainfall (mm yr ${ }^{-1}$ ) & 1400.84 & 0.1620 & -2.6963 & 3.0204 & 44 & $>0.200$ \\
\hline 1979-2001 & Rainfall (mm yr ${ }^{-1}$ ) & 1426.74 & -1.3292 & -9.6315 & 6.9730 & 23 & $>0.200$ \\
\hline 1958-2001 & Snowfall $\left(\mathrm{mm} \mathrm{yr}^{-1}\right)$ & 25.43 & 0.0716 & -0.0398 & 0.1830 & 42 & $>0.200$ \\
\hline 1979-2001 & Snowfall $\left(\mathrm{mm} \mathrm{yr}^{-1}\right)$ & 26.34 & -0.1199 & -0.4288 & 0.1890 & 14 & $>0.200$ \\
\hline 1958-2001 & Precipitation $\left(\mathrm{mm} \mathrm{yr}^{-1}\right)$ & 1426.27 & 0.2336 & -2.6439 & 3.1112 & 44 & $>0.200$ \\
\hline 1979-2001 & Precipitation $\left(\mathrm{mm} \mathrm{yr}^{-1}\right)$ & 1426.74 & -1.3292 & -9.6315 & 6.9730 & 23 & $>0.200$ \\
\hline
\end{tabular}

available, and rated their performance against Food and Agriculture Organization (FAO) reference crop evaporation used as a standard. Recently Kingston et al. (2009) compared a variety of methods for evaluating potential evapotranspiration globally under climate change.

\section{Global reference crop evaporation}

Figure 5a shows the average cumulative $\mathrm{PET}_{\text {rc }}$ per year calculated from the WFD for 1979-2001. In arid areas such as the Sahara Desert, the calculated value of $\mathrm{PET}_{\mathrm{rc}}$ far exceeds the actual evaporation (Jung et al. 2010) from natural surfaces. In fact, the areas in Fig. 5a where average $\mathrm{PET}_{\mathrm{rc}}$ exceeds $1500 \mathrm{~mm} \mathrm{yr}^{-1}$ correspond well to the hot desert areas of the globe. As mentioned earlier, $\mathrm{PET}_{\mathrm{PT}}$ is arguably an estimate of potential evaporation that is reliable in humid areas, although it has been used in this way elsewhere in GHMs (Haddeland et al. 2011). To demonstrate the discrepancy between these two alternative estimates of potential evapotranspiration, Fig. 5b shows $\mathrm{PET}_{\mathrm{PT}}$ with the same scale as Fig. 5a. This figure clearly shows that $\mathrm{PET}_{\mathrm{PT}}$ can differ locally by more than $1000 \mathrm{~mm} \mathrm{yr}^{-1}$ and confirms the findings of Kingston et al. (2009). In part this explains why in the Water Model Intercomparison Project (WaterMIP) exercise (Haddeland et al. 2011), which used the WFD for the period 1985-99, the GHMs using PET $_{\mathrm{PT}}$ (participating alongside LSMs and GHMs using $\mathrm{PET}_{\mathrm{rc}}$ ) contributed to the wide scatter in the model results for arid areas such as the upper Niger River basin, the Orange River basin, and the MurrayDarling River basin (see Fig. 6 of Haddeland et al. 2011).
Figure 6 shows changes in the global, area-weighted, annual average, cumulative PET $_{\mathrm{rc}}$ during the twentieth century derived from the WFD. The gray zone around the average values indicates the $95 \%$ confidence interval of the mean assessed across all grid boxes. This uncertainty does not include assessment of the uncertainties due to the generation of the gridded CRU data for monthly bias correction. Table 3 documents the linear trends in $\mathrm{PET}_{\mathrm{rc}}$ and associated variables and their significance as assessed from the distribution of mean values around the regression, but not their uncertainty due to uncertainties in the CRU data. Trends over the period 1901-57 are calculated separately from those over the period 1958-2001. This is because, by randomizing the order of the ERA-40 basis data, the process used to create the WFD before 1958 removes the interannual dependency of variables that were not subsequently bias-corrected (wind speed, surface pressure, specific humidity, and downward longwave radiation). This change in character of interannual variations in the WFD prior to December 1958 is reflected in the more erratic changes in $\mathrm{PET}_{\mathrm{rc}}$ and other variables in Fig. 6 relative to the more smoothly varying changes after January 1958. It is also reflected in the fact that the lag- 1 autocorrelation of global annual $\mathrm{PET}_{\mathrm{rc}}$ is 0.30 before 1957 and 0.64 afterward.

Throughout this paper linear trend significance is assessed using a Student's $t$ test in which the lag-1 autocorrelation is used to estimate the (lower) effective number of independent data points in order to allow for the influence of the serial dependence of the time series (Zwiers and von Storch 1995; von Storch and Zwiers 1999). Based on these criteria the trend in global annual 
$\mathrm{PET}_{\mathrm{rc}}$ from 1958-2001, which is $-0.51( \pm 0.20) \mathrm{mm} \mathrm{yr}^{-1}$ per year, is statistically significant (Table 3 ). However, there is no significant trend in global $\mathrm{PET}_{\mathrm{rc}}$ calculated from the WFD from 1901 to 1957.

The lack of trend globally in the earlier part of the century could be a genuine phenomenon or it may in part reflect the procedure used to generate these data by use of randomized individual years of ERA-40 basis data. Although there are increases in 2-m temperature incorporated into the WFD (1901-57) via bias correction, it is likely that the lack of monthly bias correction of wind speed, surface pressure, specific humidity, and longwave radiation meant that $\mathrm{PET}_{\mathrm{rc}}$ does not incorporate climate change trends due to the randomization of the individual years of ERA-40 basis data. Potentially the use of future early twentieth-century reanalysis data could help recover possible interannual variability in $\mathrm{PET}_{\mathrm{rc}}$. Additionally, in those locations where there were insufficient meteorological stations for interpolation prior to 1950 , CRU substituted monthly 1960-91 climatology [as discussed in section $2 b(2)$ ]. In such locations the use of CRU-substituted climatological averages in bias correction, rather than real observations, will have further led to removal of any decadal and longer trends in $\mathrm{PET}_{\mathrm{rc}}$.

The interannual variations in global $\mathrm{PET}_{\mathrm{rc}}$ are very large compared to the statistically significant linear decrease over the period 1958-2001, and they appear to have some relationship to VPD (the correlation between VPD and PET $\mathrm{rc}_{\mathrm{rc}}$ has $r^{2}=0.59, N=44$, and $P<$ 0.001). In Fig. 6 the values of PET $\mathrm{rc}_{\mathrm{rc}}$ and VPD are both noticeably higher during the period 1958-73 than during the remainder of the 1958-2000 period. Uppala et al. (2005) discussed problems with the use of observations, resulting in surface pressure in the early years of the reanalysis for the periods 1958-72 and 1973-76, which they assessed as being higher and lower, respectively, than for the period 1978-2001, when use of satellite data led to more stable, better-constrained values. Because surface pressure was not bias-corrected in the WFD it is possible that the deviations in global VPD from 1958 to 1978 shown in Fig. 6 are a symptom of this feature in the ERA-40 reanalysis. There is certainly a striking similarity between features shown in our Fig. 6 and in Fig. 10 of Uppala et al. (2005). The variations in VPD in Fig. 6 are necessarily also reflected in $\mathrm{PET}_{\mathrm{rc}}$ [Eq. (5)].

There are statistically significant increases in global VPD and also statistically significant decreases global net radiation and wind speed over the period 1979-2001 (Table 3). Despite the fact that these variables have an important influence on evaporation, global $\mathrm{PET}_{\mathrm{rc}}$ shows no statistically significant change over this period. As expected, 2-m temperatures also increase substantially over 1979-2001 (see Fig. 6 and Table 3). The lack of change in $\mathrm{PET}_{\mathrm{rc}}$ over this time is presumably because of the counteracting influences of changes in other contributing variables: VPD, net radiation, and wind speed.

\section{Regional reference crop evaporation}

Figure 1 shows the location of eight of the large river basins that are of special interest for hydrological modeling in the WATCH project. In this study trend analyses were made for $\mathrm{PET}_{\mathrm{rc}}$ and associated variables for all eight basins (Table 4) and are illustrated for four of them (Figs. 7 and 8).

Figure 7 shows that $\mathrm{PET}_{\mathrm{rc}}$ is relatively low in the Amazon and Congo basins and also agrees fairly well, in terms of annual average, with PET $_{\mathrm{PT}}$ because they lie in humid areas. In Amazonia, interannual variations in $\mathrm{PET}_{\mathrm{rc}}$ and VPD are similar to the global variations shown in Fig. 6, and PET ${ }_{\mathrm{rc}}$ had no significant trend between 1979 and 2001 although wind speed decreased significantly (Table 4a). There was also no trend in $\mathrm{PET}_{\mathrm{rc}}$ in the Congo basin from 1979 to 2001, although VPD increased significantly and there were significant decreases in wind speed and net radiation (and hence in $\mathrm{PET}_{\mathrm{PT}}$; Table $4 \mathrm{~b}$ ).

By contrast, the Niger and Murray-Darling basins (Fig. 8) have relatively high $\mathrm{PET}_{\mathrm{rc}}$ that far exceeds PET $_{\mathrm{PT}}$ because these are in arid regions. In the Niger River basin the only variable illustrated in Fig. 8 to have a significant trend over the period 1979-2001 is the wind speed (decreasing; Table 4g). In the Murray-Darling basin there is a significant decrease in $\mathrm{PET}_{\mathrm{rc}}$ over the period 1979-2001, which is probably associated with a significant decrease in VPD (Table 4d). Given the lack of a global trend in $\mathrm{PET}_{\mathrm{rc}}$ in the period 1979-2001 (see Fig. 6 ; Table 3), the significant downward trend in the MurrayDarling basin is clearly compensated by simultaneous increases elsewhere, providing a reminder that global changes are an amalgam of conflicting regional changes.

\section{Global and regional precipitation}

As previously explained, monthly precipitation totals were established for 1901-2001 by combining GPCCv4 observed totals with wet-day corrections, ERA-40 rainfall-snowfall proportions, and precipitation gauge catch corrections. Consequently, in theory interannual trends in precipitation in the WFD in the period 1901-57 are based on observations, and the reordering of ERA-40 basis precipitation data prior to bias correction does not destroy evidence of climatically significant change. However, the coverage of precipitation gauges in the early part of the century is very sparse in many regions prior to 1950 . Consequently, global trends in precipitation prior to 1957 have not been assessed because the variable station 

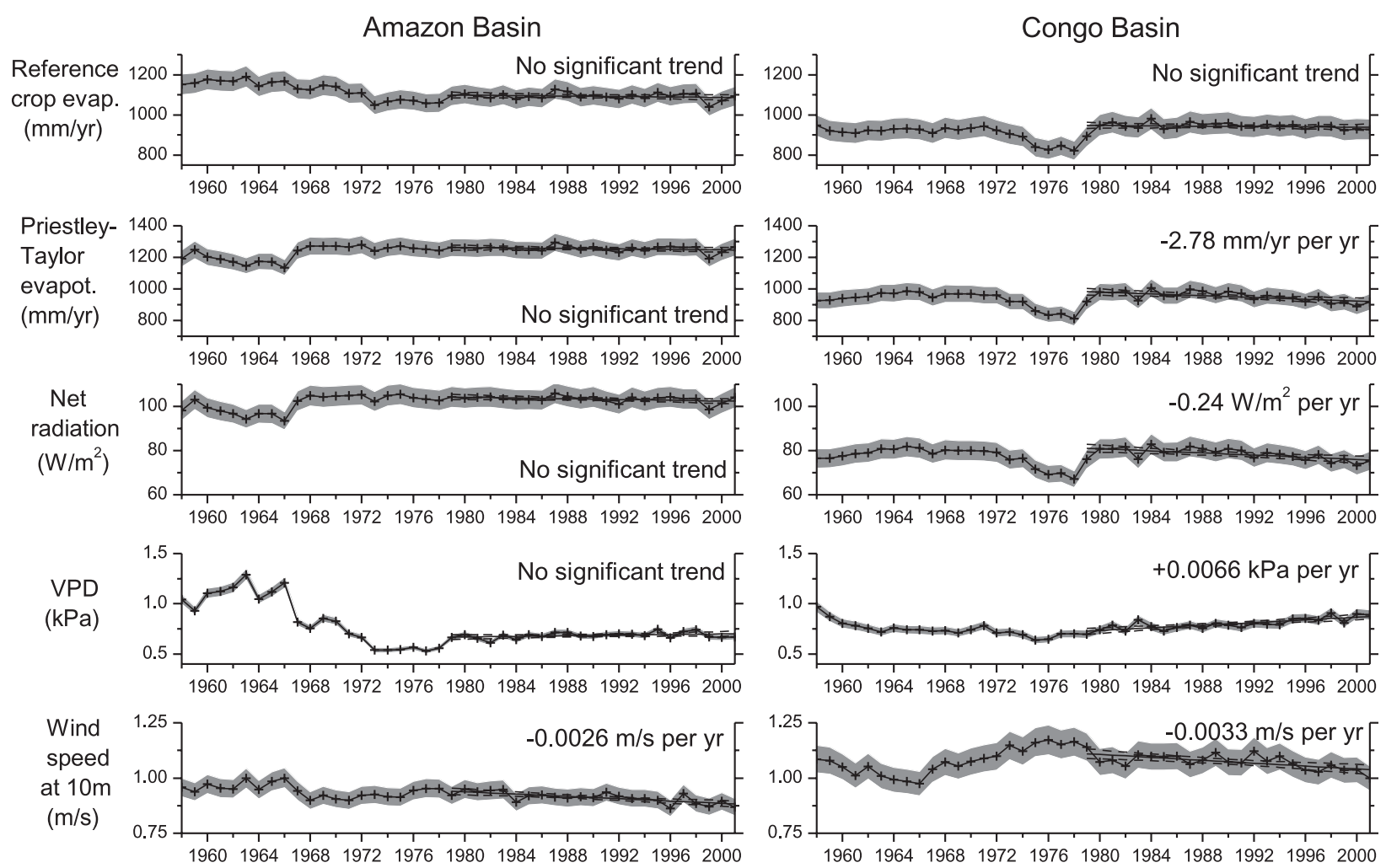

FIG. 7. Interannual variability of (top to bottom) reference crop evaporation and associated variables for the (left) Amazon and (right) the Congo River basins in the late twentieth century based on the WFD (see Tables 4a and 4b, respectively). The format is as in Fig. 6. Trend analysis results shown relate to 1979-2001 only (cf. Table 4).

coverage may have caused substantial bias in the global average values. After 1958 there is still much sparser coverage in the observing network at high latitudes (e.g., Mackenzie and Lena River basins) and in low latitudes (e.g., Amazon and Congo River basins) in comparison to midlatitudes (New et al. 1999, 2000; Fuchs et al. 2009). Consequently, the assessments of regional trends discussed below are likely to be less reliable than for midlatitude regions with the highest density of observation networks.

The WFD show no significant changes in precipitation from 1958-2001 (Fig. 9; Table 3). Globally precipitation slightly exceeds actual evaporation over land (Trenberth et al. 2007). However, $\mathrm{PET}_{\mathrm{rc}}$ is slightly larger than precipitation (shown respectively as dashed lines and lines with plus symbols in Fig. 9), although this is not surprising given that over large areas of the land surface the average reference crop evaporation exceeds average actual evaporation (cf. our Fig. 5a and Fig. 1a of Jung et al. 2010).

High-latitude cold river basins such as the Mackenzie and Lena River basins exhibit very large interannual variations in total precipitation (including snowfall), which is not seen in $\mathrm{PET}_{\mathrm{rc}}$ although the average values are similar (Fig. 9). The Mackenzie basin had decreasing snowfall from 1958-2001, but no changes in rainfall
(Table 4e). The Lena basin had no significant change in either form of precipitation late in the century. The Amazon and Congo basins are relatively humid and precipitation (which is almost exclusively rainfall) far exceeds $\mathrm{PET}_{\mathrm{rc}}$, leading to substantial runoff (Fig. 9). Rainfall apparently remained approximately constant in the Amazon basin. There were no significant changes in precipitation in the Ganges-Brahamaputra basin over 1958-2001, but there were significant decreases in the Congo River basin over the same period (though not over 1979-2001; Table 4).

Basins in arid regions such as the Murray-Darling River basin have relatively low precipitation that is almost entirely rainfall, with very large interannual variations relative to the mean (Fig. 9). These have significant implications for water resources management. In such basins potential evapotranspiration also greatly exceeds precipitation (Fig. 9; Table 4). However, the WFD show no significant trends in cumulative annual precipitation in the Murray-Darling and the Orange River basins over 1958-2001 (Table 4). Note, however, that this trend analysis does not investigate interannual changes in precipitation intensity, which may be important. The Niger River basin apparently had significantly decreasing rainfall over 1958-2001, though not over 1979-2001 (Table 4g). 

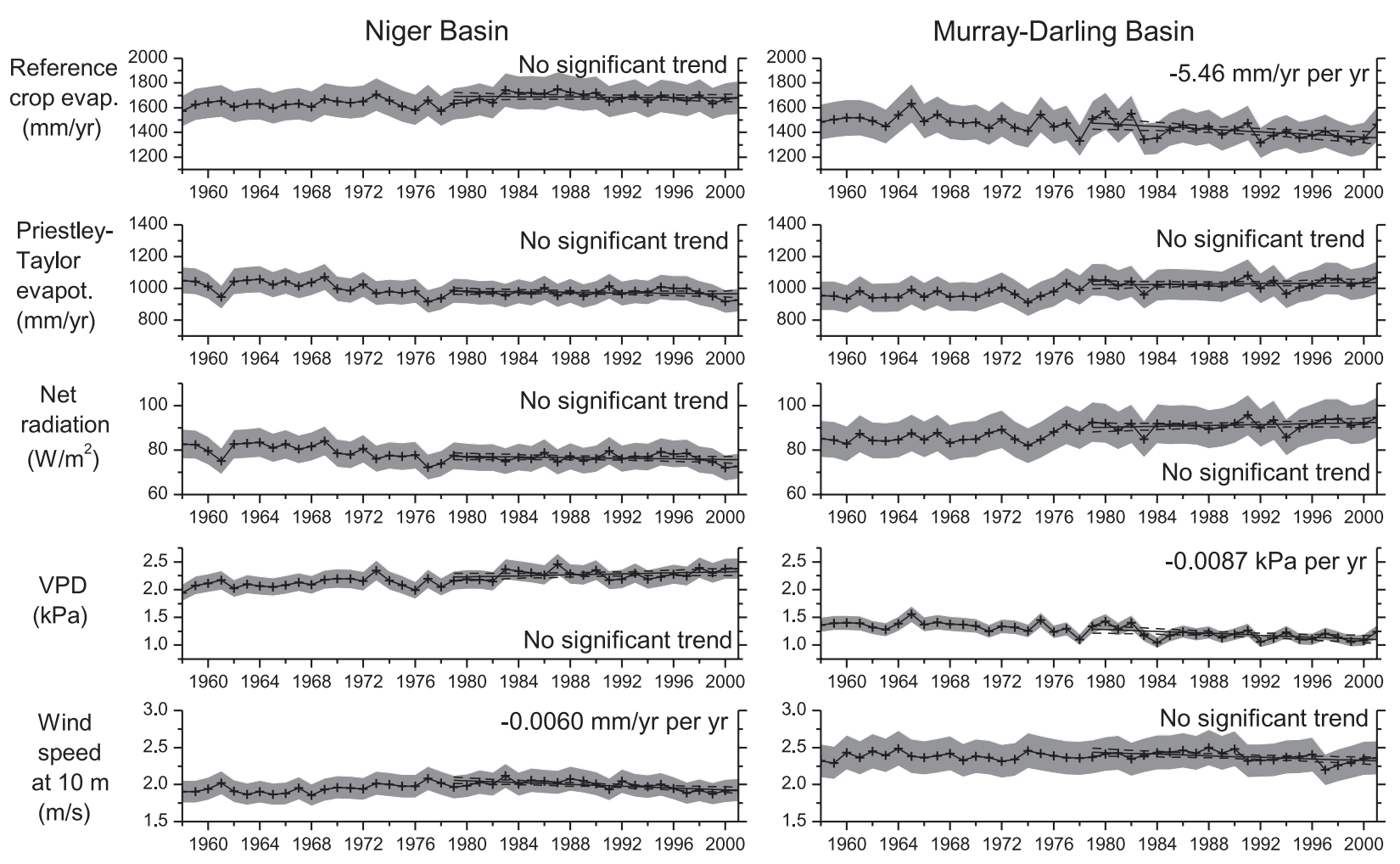

FIG. 8. As in Fig. 7, but for the Niger and Murray-Darling River basins (see Tables 4g and 4d, respectively).

\section{Conclusions}

This paper describes the Watch Forcing Data (WFD) created at half-degree resolution for the purpose of driving LSMs and GHMs through the twentieth century. For the period 1958-2001 the WFD can be considered to provide a good representation of real meteorological events, synoptic activity, seasonal cycles, and climate trends. The WFD for the period 1901-57 were constructed to have similar subdaily to seasonal statistical characteristics (including averages, extremes, covariance between meteorological variables, and subdaily to seasonal autocorrelation) as for the period 1958-2001. For the period 1901-57 the WFD can therefore be used to characterize early twentieth-century subdaily to seasonal hydrological statistics, but they do not represent particular historical events. There is a lack of interannual-decadal variability in $\mathrm{PET}_{\mathrm{rc}}$ for 1901-57 despite the trends in 2-m temperature introduced by bias correction as a result of 1) the randomization of the ERA-40 data used in construction and 2) lack of bias correction of wind speed, surface pressure, specific humidity, and downward longwave radiation, combined with in some regions with 3 ) the substitution of climatology for observations in some bias-correction data (especially cloud cover) as a result of limited observations. Potentially, effort directed toward bias correction variables (point 2) and/or use of future 1901-57 reanalysis products will alleviate these shortcomings. Nevertheless, because they are bias corrected and based directly on reanalysis, the WFD for the period 1958-2001 do include observed climatological trends in monthly to interannual changes in 2-m temperature, downward shortwave radiation, and precipitation.

When making the wet-day corrections, care was taken to avoid destroying the spatial coherence of significant precipitation events associated with frontal systems that occur across several half-degree grid squares. The WFD precipitation data also preserve the same mixture of rainfall and snowfall as in the original ERA-40 reanalysis rather than using a simplistic rain/snow threshold based on 2-m temperature. Validation against flux tower data aggregated to 3-h time steps shows that the WFD are least satisfactory in terms of describing subdaily variations in precipitation, but at monthly and longer time scales most variables show a very good level of agreement with field observations despite the difference in the spatial scales to which the WFD and flux station data relate.

Globally (excluding Antarctica), rainfall and snowfall on land remained approximately constant from 1958-2001, but is difficult to assess prior to 1957 because of inadequate and variable gauge coverage and after this time there are several areas where the changes inferred here may be biased by inadequate gauge station coverage. Snowfall apparently decreased in the Mackenzie Basin in the period 1957 to 
Ref. crop e. 1200 Global land

Precip. and

Snowfall

(mm/yr)

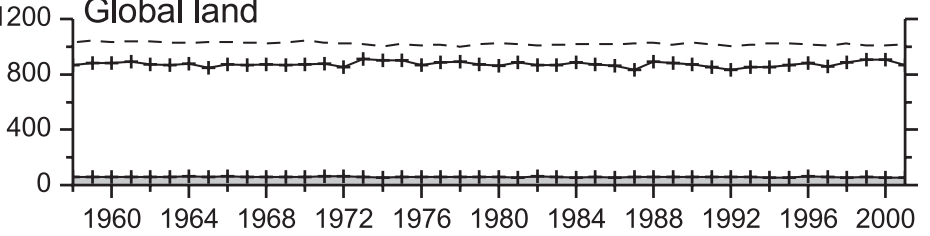

Ref. crop e.

Precip. and

Snowfall

(mm/yr)

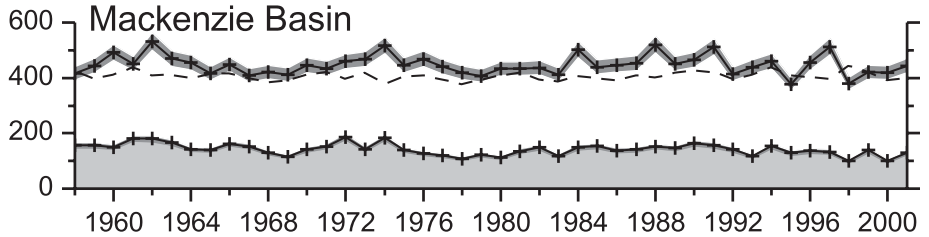

Ref. crop e.

Precip. and

Snowfall

(mm/yr)

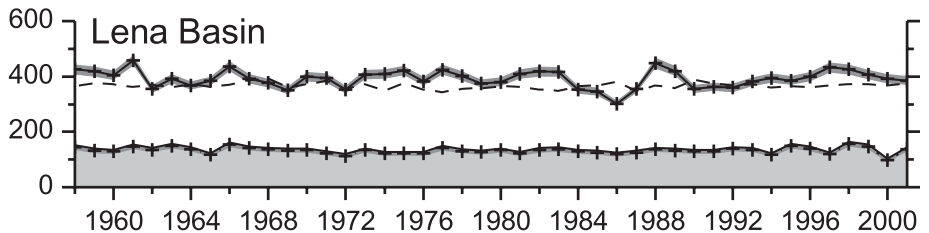

Ref. crop e.

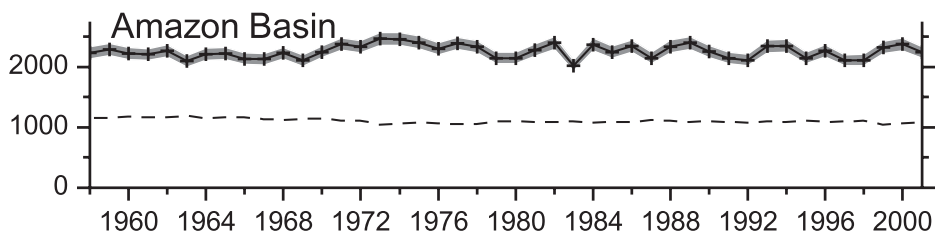

Ref. crop e.

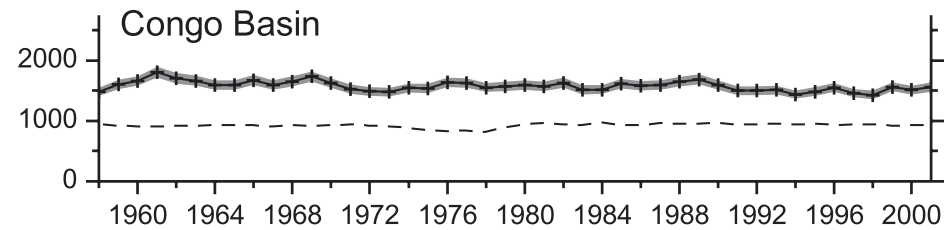

Ref. crop e.

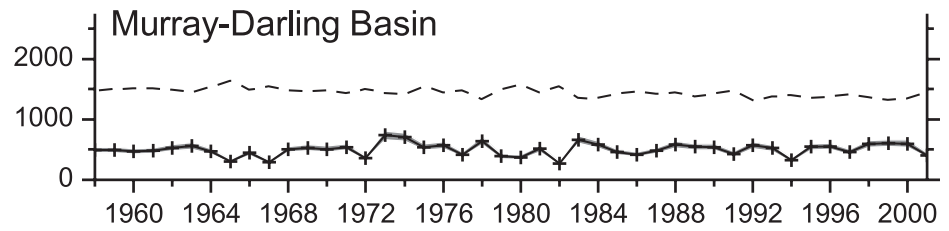

FIG. 9. Average cumulative annual precipitation and snowfall compared to average reference crop evaporation for 1958-2001 for (top) global land (excluding Antarctica) and (next row to bottom) selected large river basins. All averages are area weighted. Average reference crop evaporation is indicated using the near-horizontal dashed lines. The precipitation and snowfall averages are shown as continuous lines and plus signs with $95 \%$ confidence intervals displayed using gray shading. The snowfall proportions of precipitation are emphasized using light gray shading below the lower $95 \%$ confidence limit of the means at the bottom of the top three panels (there is negligible snowfall in the Amazon and Murray River basins and none in the Congo River basin; Table 4).

2001. Rainfall decreased in the Congo and Niger River basins after 1958 (Table 4). There were no significant trends in precipitation in the Ganges-Brahmaputra, Orange, or Murray-Darling River basins in the twentieth century although no account was taken of interannual changes in the intensity of precipitation events in the trend analysis used.

Recognized problems with the global average surface pressure in the ERA-40 reanalysis in the period 1958-78 may well have affected calculations of global average VPD from the WFD and thence global average PET ${ }_{\mathrm{rc}}$, and interannual variations in these two variables over this time period are probably spurious. The interannual variations in VPD and $\mathrm{PET}_{\mathrm{rc}}$ in the Amazon basin (but not the other basins studied) appear to reflect the same problems as the global data in the period 1958 to 1978. 
Globally, annual average $\mathrm{PET}_{\mathrm{rc}}$ calculated using the WFD exhibits no significant change over the period 1979 to 2001 despite simultaneous significant increases in VPD and simultaneous significant decreases in net radiation and wind speed. However, the lack of overall change in global $\mathrm{PET}_{\mathrm{rc}}$ shrouds conflicting regional changes. There was, for example, a significant decrease in annual average cumulative $\mathrm{PET}_{\mathrm{rc}}$ in the Murray-Darling basin that was associated with an increase in VPD.

Acknowledgments. We thank Jan Polcher for suggesting use of the ERA-40 data as the basis for the WFD for the period 1901 to 1957, and Nigel Arnell for suggesting that corrections should be made to both rainfall and snowfall for each month. We acknowledge permission to use flux tower observations given by Steven Wofsy, Alesandro Araújo, Celso von Randow, Bart Kruijt, Christian Bernhofer, Thomas Grünwald, Timo Vesala, Giorgio Matteucci, and Marc Aubinet. This research was undertaken within the EU FP6 project WATCH (Contract 036946). GPW, NB, OB, and MB were supported by the Joint DECC/Defra Met Office Hadley Centre Climate Programme (GA01101).

\section{APPENDIX}

\section{ERA-40 Data Extraction Order}

TABLE A1. The order of the ERA-40 basis years as used in the WFD 1901-57.

\begin{tabular}{lccccc}
\hline \hline $\begin{array}{l}\text { WFD } \\
\text { year }\end{array}$ & $\begin{array}{c}\text { ERA-40 } \\
\text { basis } \\
\text { year }\end{array}$ & $\begin{array}{c}\text { WFD } \\
\text { year }\end{array}$ & $\begin{array}{c}\text { ERA-40 } \\
\text { basis } \\
\text { year }\end{array}$ & $\begin{array}{c}\text { WFD } \\
\text { year }\end{array}$ & $\begin{array}{c}\text { ERA-40 } \\
\text { basis } \\
\text { year }\end{array}$ \\
\hline 1901 & 1974 & 1920 & 1984 & 1939 & 1969 \\
1902 & 1958 & 1921 & 1987 & 1940 & 1980 \\
1903 & 1986 & 1922 & 1961 & 1941 & 1970 \\
1904 & 1976 & 1923 & 1977 & 1942 & 1995 \\
1905 & 1988 & 1924 & 1966 & 1943 & 1982 \\
1906 & 1983 & 1925 & 1973 & 1944 & 1971 \\
1907 & 1979 & 1926 & 1968 & 1945 & 1975 \\
1908 & 1974 & 1927 & 1959 & 1946 & 1962 \\
1909 & 1998 & 1928 & 2001 & 1947 & 1964 \\
1910 & 1962 & 1929 & 1979 & 1948 & 1982 \\
1911 & 1992 & 1930 & 1994 & 1949 & 1978 \\
1912 & 1985 & 1931 & 1989 & 1950 & 1992 \\
1913 & 1967 & 1932 & 1991 & 1951 & 1981 \\
1914 & 1972 & 1933 & 1991 & 1952 & 1986 \\
1915 & 1980 & 1934 & 2000 & 1953 & 1996 \\
1916 & 1965 & 1935 & 1999 & 1954 & 1987 \\
1917 & 1966 & 1936 & 1998 & 1955 & 1997 \\
1918 & 1993 & 1937 & 1963 & 1956 & 1977 \\
1919 & 1990 & 1938 & 1960 & 1957 & 1993 \\
\hline
\end{tabular}

\section{REFERENCES}

Adam, J. C., and D. P. Lettenmaier, 2003: Adjustment of global gridded precipitation for systematic bias. J. Geophys. Res., 108, 4257, doi:10.1029/2002JD002499.

— E. A. Clark, D. P. Lettenmaier, and E. F. Wood, 2006: Correction of global precipitation for orographic effects. J. Climate, 19, 15-38.

Allen, R. G., L. S. Pereira, D. Raes, and M. Smith, 1998: Crop evapotranspiration: Guidelines for computing crop water requirements. FAO Irrigation and Drainage Paper 56. [Available online at http://www.fao.org/docrep/X0490E/x0490e00.htm.]

Araújo, A. C., and Coauthors, 2002: Comparative measurements of carbon dioxide fluxes from two nearby towers in a central Amazonian rainforest: The Manaus LBA site. J. Geophys. Res., 107, 8090, doi:10.1029/2001JD000676.

Aubinet, M., B. Chermanne, M. Vandenhaute, B. Longdoz, M. Yernaux, and E. Laitat, 2001: Long term carbon dioxide exchange above a mixed forest in the Belgian Ardennes. $\mathrm{Ag}$ ric. For. Meteor., 108, 293-315.

Bellouin, N., O. Boucher, J. Haywood, C. Johnson, A. Jones, J. Rae, and S. Woodward, 2007: Improved representation of aerosols for HadGEM2. Hadley Centre Tech. Note 73, 43 pp. [Available online at http://www.metoffice.gov.uk/publications/ HCTN/HCTN_73.pdf.]

Betts, A. K., and A. C. M. Beljaars, 2003: ECMWF ISLSCP-II near-surface dataset from ERA-40. ERA-40 Project Rep. Series 8, 31 pp. [Available online at http://www.ecmwf. int/publications/library/do/references/show?id=85944.]

Bouchet, R. J., 1963: Evapotranspiration reelle, evapotranspiration potentielle et production agricole. Ann. Agron., 14, 743-824.

Brohan, P., J. J. Kennedy, I. Harris, S. F. B. Tett, and P. D. Jones, 2006: Uncertainty estimates in regional and global observed temperature changes: A new data set from 1850. J. Geophys. Res., 111, D12106, doi:10.1029/2005JD006548.

Collins, W. J., and Coauthors, 2008: Evaluation of HadGEM2 model. Hadley Centre Tech. Note 74, 47 pp. [Available online at http://www.metoffice.gov.uk/publications/HCTN/HCTN_74 pdf.]

Cosgrove, B. A., and Coauthors, 2003: Real-time and retrospective forcing in the North American Land Data Assimilation System (NLDAS) project. J. Geophys. Res., 108, 8842, doi:10.1029/ 2002JD003118.

Dang, H., N. P. Gillett, A. J. Weaver, and F. W. Zwiers, 2007: Climate change detection over different land surface vegetation classes. Int. J. Climatol., 27, 211-220.

Déry, S. J., and E. F. Wood, 2005: Observed twentieth century land surface air temperature and precipitation covariability. Geophys. Res. Lett., 32, L21414, doi:10.1029/2005GL024234.

Ebisuzaki, W., 1997: A method to estimate the statistical significance of a correlation when data are serially correlated. J. Climate, 10, 2147-2153.

Fuchs, T., and Coauthors, 2009: GPCC annual report for year 2008: Development of the GPCC data base and analysis products. Global Precipitation Climatology Centre, 13 pp. [Available online at http://www.gpcc.dwd.de.]

Gedney, N., P. M. Cox, R. A. Betts, O. Boucher, C. Huntingford, and P. A. Stott, 2006: Detection of a direct carbon dioxide effect in continental river runoff. Nature, 439, 835-838.

Göckede, M., and Coauthors, 2008: Quality control of CarboEurope flux data-Part 1: Coupling footprint analyses with flux data quality assessment to evaluate sites in forest ecosystems. Biogeosciences, 5, 433-450. 
Grünwald, T., and C. Bernhofer, 2007: A decade of carbon, water and energy flux measurements of an old spruce forest at the Anchor Station Tharandt. Tellus, 59B, 387-396.

Haddeland, I., and Coauthors, 2011: Multimodel estimate of the global terrestrial water balance: Setup and first results. J. Hydrometeor., 12, 869-884.

Hagemann, S., K. Arpe, and L. Bengtsson, 2005: Validation of the hydrological cycle of ERA-40. ERA-40 Project Rep. Series 24 $42 \mathrm{pp}$.

Harding, R. J., and Coauthors, 2011: Preface to "Water and Global Change (WATCH) special collection: Current knowledge of the terrestrial global water cycle." J. Hydrometeor., in press.

Hobbins, M. T., A. Dai, M. L. Roderick, and G. D. Farquahar, 2008: Revisiting the parameterization of potential evaporation as a driver of long-term water balance trends. Geophys. Res. Lett., 35, L12403, doi:10.1029/2008GL033840.

Jung, M., and Coauthors, 2010: Recent decline in the global land evapotranspiration trend due to limited moisture supply. $\mathrm{Na}$ ture, 467, 951-954

Kingston, D. G., M. C. Todd, R. G. Taylor, J. R. Thompson, and N. W. Arnell, 2009: Uncertainty in the estimation of potential evapotranspiration under climate change. Geophys. Res. Lett., 36, L20403, doi:10.1029/2009GL040267.

Lu, J., G. Sun, S. G. McNulty, and D. M. Amatya, 2005: A comparison of six potential evapotranspiration methods for regional use in the southeastern United States. J. Amer. Water Resour. Assoc., 41, 621-633, doi:10.1111/j.1752-1688.2005.tb03759.x.

Mann, M. E., and J. Lees, 1996: Robust estimation of background noise and signal detection in climatic time series. Climatic Change, 33, 409-445.

Martin, G. M., M. A. Ringer, V. A. Pope, A. Jones, C. Dearden, and T. J. Hinton, 2006: The physical properties of the atmosphere in the new Hadley Centre Global Environmental Model (HadGEM1). Part I: Model description and global climatology. J. Climate, 19, 1274-1301.

Meyers, T. P., and S. E. Hollinger, 2004: An assessment of storage terms in the surface energy balance of maize and soybean. Agric. For. Meteor., 125, 105-115.

Mitchell, T. D., and P. D. Jones, 2005: An improved method of constructing a database of monthly climate observations and associated high-resolution grids. Int. J. Climatol., $\mathbf{2 5}$ 693-712.

Monteith, J. L., 1965: Evaporation and environment. Symp. Soc. Exp. Biol., 19, 205-234.

New, M., M. Hulme, and P. Jones, 1999: Representing twentiethcentury space-time climate variability. Part I: Development of a 1961-90 mean monthly terrestrial climatology. J. Climate, 12, 829-856.

- ——, and — 2000: Representing twentieth-century space-time climate variability. Part II: Development of 1901-96 monthly grids of terrestrial surface climate. J. Climate, 13, 2217-2238.

Ngo-Duc, T., J. Polcher, and K. Laval, 2005: A 53-year forcing data set for land surface models. J. Geophys. Res., 110, D06116, doi:10.1029/2004JD005434.

Österle, H., F.-W. Gertengarbe, and P. C. Werner, 2003: Homogenisierung und Aktualisierung des Klimadatensatzes der Climate Research Unit der University of East Anglia, Norwich. Terra Nostra, 6, 326-329.

Persson, T., and Coauthors, 2000: Experimental sites in the NYPHYS/ CANIF project. Carbon and Nitrogen Cycling in European Forest Ecosystems, E.-D. Schulze, Ed., Ecological Studies Series 142, Springer Verlag, 14-48.
Piao, S., P. Ciais, P. Friedlingstein, N. de Noblet-Ducoudré, P. Cadule, N. Viovy, and T. Wang, 2009: Spatiotemporal patterns of terrestrial carbon cycle during the 20th century. Global Biogeochem. Cycles, 23, GB4026, doi:10.1029/ 2008GB003339.

Pitman, A. J., and S. E. Perkins, 2009: Global and regional comparison of daily $2-\mathrm{m}$ and $1000-\mathrm{hPa}$ maximum and minimum temperatures in three global reanalyses. J. Climate, 22, 46674681.

Press, W. H., S. A. Teukolsky, W. T. Vetterling, and B. P. Flannery, 1992: Numerical Recipes in FORTRAN: The Art of Scientific Computing. Cambridge University Press, $963 \mathrm{pp}$.

Priestley, C. H. B., and R. J. Taylor, 1972: On the assessment of surface heat flux and evaporation using large-scale parameters. Mon. Wea. Rev., 100, 81-92.

Roderick, M. L., and G. D. Farquhar, 2002: The cause of decreased pan evaporation over the last 50 years. Science, 298, 1410 1411

—, L. D. Rotstayn, G. D. Farquhar, and M. T. Hobbins, 2007: On the attribution of changing pan evaporation. Geophys. Res. Lett., 34, L17403, doi:10.1029/2007GL031166.

Rudolf, B., and U. Schneider, 2005: Calculation of gridded precipitation data for the global land-surface using in-situ gauge observations. Proc. Second Workshop of the International Precipitation Working Group, Monterey, CA, IPWG, 231-247.

Sato, M., J. E. Hansen, M. P. McCormick, and J. B. Pollack, 1993: Stratospheric aerosol optical depth, 1850-1990. J. Geophys. Res., 98, 22 987-22 994.

Schneider, U., T. Fuchs, A. Meyer-Christoffer, and B. Rudolf, 2008: Global precipitation analysis products of the GPCC. Global Precipitation Climatology Centre, $12 \mathrm{pp}$.

Sheffield, J., A. D. Ziegler, E. F. Wood, and Y. Chen, 2004: Correction of the high-latitude rain day anomaly in the NCEPNCAR reanalysis for land surface hydrological modeling. J. Climate, 17, 3814-3828

, G. Goteti, and E. F. Wood, 2006: Development of a 50-year high-resolution global dataset of meteorological forcings for land surface modeling. J. Climate, 19, 3088-3111.

Shuttleworth, W. J., 2006: Towards one-step estimation of crop water requirements. Trans. Amer. Soc. Agric. Biol. Eng., 49, 925-935

, A. Serrat-Capdevila, M. L. Roderick, and R. L. Scott, 2009: On the theory relating changes in area-average and pan evaporation. Quart. J. Roy. Meteor. Soc., 135, 1230-1247.

Simmons, A. J., and Coauthors, 2004: Comparison of trends and low-frequency variability in CRU, ERA-40, and NCEP/ NCAR analyses of surface air temperature. J. Geophys. Res., 109, D24115, doi:10.1029/2004JD005306.

Suni, T., and Coauthors, 2003: Long-term measurements of surface fluxes above a Scots pine forest in Hyytiälä, southern Finland, 1996-2001. Boreal Env. Res., 8, 287-301.

Trenberth, K. E., L. Smith, T. Qian, A. Dai, and J. Fasullo, 2007: Estimates of the global water budget and its annual cycle using observational and model data. J. Hydrometeor., 8, $758-769$.

Troy, T. J., and E. F. Wood, 2009: Comparison and evaluation of gridded radiation products across northern Eurasia. Environ. Res. Lett., 4, 045008, doi:10.1088/1748-9326/4/4/045008.

Uppala, S. M., and Coauthors, 2005: The ERA-40 Re-Analysis. Quart. J. Roy. Meteor. Soc., 131, 2961-3012.

Urbanski, S., and Coauthors, 2007: Factors controlling $\mathrm{CO}_{2}$ exchange on timescales from hourly to decadal at Harvard Forest. J. Geophys. Res., 112, G02020, doi:10.1029/2006JG000293. 
von Storch, H., and F. W. Zwiers, 1999: Statistical Analysis in Climate Research. Cambridge University Press, 484 pp.

Weedon, G. P., S. Gomes, P. Viterbo, H. Österle, J. C. Adam, N. Bellouin, O. Boucher, and M. Best, 2010: The WATCH forcing data 1958-2001: A meteorological forcing dataset for land surface and hydrological models. WATCH Tech. Rep. 22, 41 pp. [Available online at http://www.eu-watch.org/publications/ technical-reports.]
Wild, M., J. Grieser, and C. Schär, 2008: Combined surface solar brightening and increasing greenhouse effect support recent intensification of the global land-based hydrological cycle. Geophys. Res. Lett., 35, L17706, doi:10.1029/ 2008GL034842.

Zwiers, F. W., and H. von Storch, 1995: Taking serial correlation into account in tests of the mean. J. Climate, 8, 336351. 